\title{
OCORRÊNCIA DE BESOUROS COPRÓFAGOS E AVALIAÇÕES MICROCLIMÁTICAS EM MASSAS FECAIS DE BOVINOS, VISANDO AO CONTROLE BIOLÓGICO DE Haematobia irritans (LINNÉ, 1758) (DIPTERA; MUSCIDAE) EM PIRACICABA/SP
}

\author{
SÉRGIO ROBERTO RODRIGUES
}

Engenheiro Agrônomo

Orientador: Prof. Dr. LUIS CARLOS MARCBINI

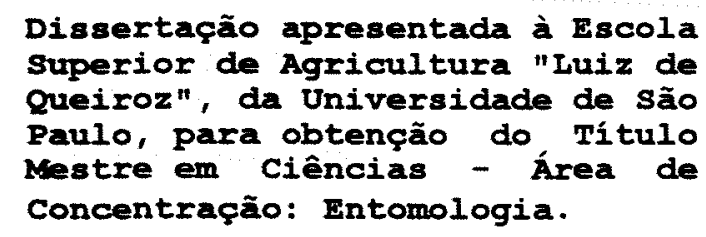

PIRACICABA

Estado de São Paulo - Brasil

Novembro - 1996 


\section{Dados Internacionais de Catalogação na Publicação (CIP) DIVISÃO DE BIBLIOTECA E DOCUMENTAÇÃO - Campus "Luiz de Queiroz"/USP}

Rodrigues, Sérgio Roberto

Ocorrência de besouros coprófagos e avaliaçōes microclimáticas em massas fecais de bovinos, visando ao controle biológico de Haematobia irritans (LINNÉ, 1758) (Diptera; Muscidae) em Piracicaba/SP / Sérgio Roberto Rodrigues . - Piracicaba, 1996.

87p. : il.

Dissertação (mestrado) - Escola Superior de Agricultura Luiz de Queiroz, 1996.

Bibliografia.

1. Armadilha para inseto 2. Besouro coprófago - Ocorrência 3. Controle biológico 4. Mosca-dos-chifres - Controle biológico I. Titulo 


\begin{abstract}
OCORRÊNCIA DE BESOUROS COPRÓFAGOS E AVALIAÇÕES MICROCLIMÁTICAS EM MASSAS FECAIS DE BOVINOS, VISANDO AO CONTROLE BIOLÓGICO DE Haematobia irritans (LINNÉ, 1758) (DIPTERA, MUSCIDAE) EM PIRACICABA/SP
\end{abstract}

SÉRGIO ROBERTO RODRIGUES

Aprovada em: 04/02/1997

Comissão Julgadora:

$\begin{array}{ll}\text { Prof. Dr. Luis Carlos Marchini } & \text { ESALQ/USP } \\ \text { Prof. Dr. Sérgio Batista Alves } & \text { ESALQ/USP } \\ \text { Prof. Dr. Paulo Sérgio Machado Botelho } & \text { CCA/UFSCAR }\end{array}$

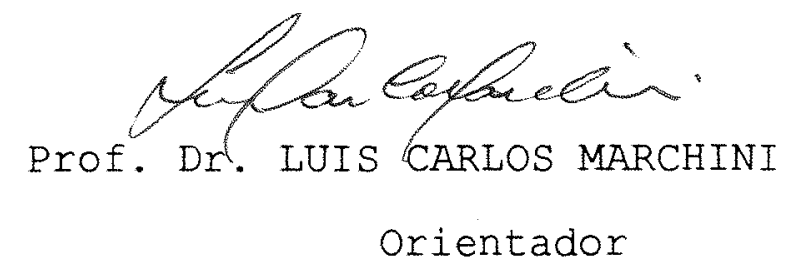


Aos meus pais,

José e Neusa

DEDICO

A minha esposa,

Andréa

OFEREÇO 


\section{AGRADECIMENTOS}

- A Coordenação de Aperfeiçoamento de Pessoal de Nível Superior (CAPES) e à Escola Superior de Agricultura "Luiz de Queiroz", da Universidade de São Paulo (ESALQ/USP), pela concessão da bolsa de estudos e oportunidade de realizar o curso de Pós-Graduação.

- A Fundação de Amparo a Pesquisa do Estado de São Paulo (FAPESP), pela concessão de verbas para aquisição de material de pesquisa.

- Ao Dr. Luis Carlos Marchini, Professor do Departamento de Entomologia da ESALQ/USP, pela orientação, amizade e constante apoio durante a realização do curso.

- A Dra. Marinéia Lara Haddad pelo auxílio nas análises estatísticas.

- Ao Eng ${ }^{\circ}$ Agr ${ }^{\circ}$ Valmir Antônio Costa, Pesquisador do Instituto Biológico de São Paulo, pelo auxílio na elaboração de fotos para ilustração do trabalho.

- Ao Eng ${ }^{\circ}$ Agr ${ }^{\circ}$ Anderson Dionei Grützmacher, pelo auxílio nas análises faunísticas dos insetos coletados. 
- Ao Eng ${ }^{\circ}$ Agr ${ }^{\circ}$ Carlos Alfredo Lopes de Carvalho pelo auxílio na leitura e correções da dissertação.

- As bibliotecárias Kátia Maria de Andrade Ferraz e Eliana Maria Garcia, pela revisão das referências bibliográficas.

- Ao Prof. Dr. Evoneo Berti Filho, pela confecção do "Summary". 


\section{SUMÁRIO}

LISTA DE TABELAS . . . . . . . . . . . . . . v viii LISTA DE FIGURAS . . . . . . . . . . . . . . . . xi RESUMO . . . . . . . . . . . . . . . . . . X XiV SUMMARY . . . . . . . . . . . . . . . . . $\mathrm{XV}$

1. INTRODUÇÃO . . . . . . . . . . . . . . . . . . . . 1

2. REVISÃO DE LITERATURA . . . . . . . . . . . 3

2.1. Mosca-dos-chifres (Haematobia irritans) . . . 3 2.1.1. Dados Biológicos ......... . 3

2.1.2. Danos e Alternativas para Controle . . . 4

2.2. Besouros coprófagos . . . . . . . . . . 6

2.2.1. Distribição de Espécies nas Regiões do

Brasil . . . . . . . . . . . . . . 6

2.2.2. Influência da Vegetação na Distribuição

das espécies . . . . . . . . . . . 8

2.2.3. Aspectos Biológicos ........ 10 
2.2.4. Controle de Moscas e Helmintos . . . . 14 2.3. Estudo da Massa Eecal . . . . . . . . . . . 18

3. MATERIAL E MÉTODOS . . . . . . . . . . . . . . . . 20

3.1. Localização do Experimento . . . . . . . . . 20

3.2. Besouros Coprófagos . . . . . . . . . . . . . 20

3.2.1. Coleta em Dois Ambientes . . . . . . . 20

3.2.2. Análise Faunística . . . . . . . . 22

3.3. Estudo das temperaturas na Massa Fecal e

Ambiente . . . . . . . . . . . . . . . . 26

3.3.1. Determinação das Temperaturas . . . . 26

3.3.2 Análise Estatística . . . . . . . . 28

3.4. Determinação das Exigências Térmicas de

H. irritans . . . . . . . . . . . . . . . . . 28

3.5. Dados Meteorológicos . . . . . . . . . . . 29

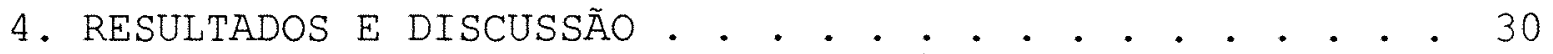

4.1. Espécies Coletadas . . . . . . . . . . . 30

4.1.1. Espécies na área de pastagem . . . . . 31

4.1.2. Espécies na área de Eucalyptus sp.

com sub-bosque . . . . . . . . . . . . . 35

4.1.3. Preferência por ambientes . . . . . . 36

4.2. Caracterização das comunidades . • . . . . . 37

4.2.1. Indíces de frequência, abundância,

constância e diversidade nas diferentes áreas • 37 
4.2.1.1. Área de pastagem . . . . . . . 37

4.2.1.2. Área de Eucalyptus sp. com sub-bosque . 39

4.2.2. Indice de diversidade . . . . . . . . 40

4.2.3. Índice de similaridade .. . . . . . 41

4.3. Temperaturas nas diferentes áreas ... . . . . 41

4.4. Importância das espécies para a pastagem . . . 44

4:5. Temperaturas em massas fecais e na pastagem . . 46

4.5.1. Comportamento ao longo dos meses . . . 46

4.5.2. Comportamento em diferentes horários

durante 0 dia ............... 51

4.5.3. Previsão de temperaturas em massas fecais 57

4.5.4. Previsão de desenvolvimento de

H. irritans . . . . . . . . . . . . 62

5. CONCLUSÕES . . . . . . . . . . . . . 67

REFERÊNCIAS BIBLIOGRÁFICAS . . . . . . . . . . 68

APÊNDICE . . . . . . . . . . . . . . . 85 
viii

\section{LISTA DE TABELAS}

1. Total de Scarabaeidae coprófagos coletados em área de pastagem, durante o período de 01/03 a 25/10/1996

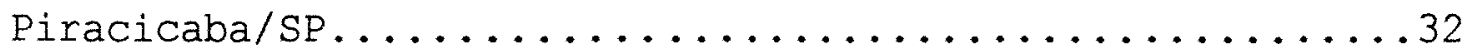

2. Total de Scarabaeidae coprófagos coletados em área de Eucalyptus sp. com sub-bosque, durante o período de 01/03

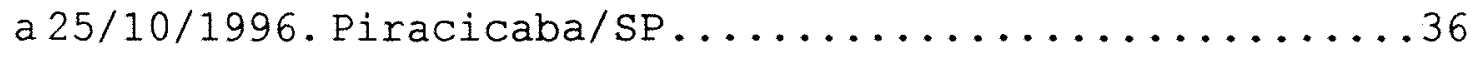

3. Distribuição porcentual das espécies capturadas com armadilha "pitfall" em área de pastagem, durante o período de $01 / 03$ a 25/10/1996. Piracicaba/sP ................. 38

4. Distribuição porcentual das espécies capturadas com armadilha "pitfall" em área deEucalyptus sp. com subbosque, durante o período de 01/03 a 25/10/1996.

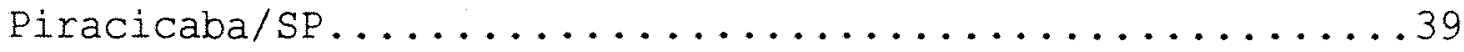


5. Número de espécies (S), número de indivíduos (N) e indice de diversidade $(\alpha)$, referentes aos diferentes locais de coletas de besouros coprófagos, durante o período de 01/03 a 25/10/1996. Piracicaba/sP ...................40

6. Número de espécies coletadas, espécies comuns, quociente de similaridade (QS) e porcentagem de similaridade (S) entre as áreas estudadas, durante 0 período de 01/03 a 25/10/1996. Piracicaba/SP .................41

7. Valores médios de temperaturas obtidas para áreas de pastagens e Eucalyptus sp. com sub-bosque na superfície do solo e a um metro de altura nos ambientes, durante o período de 01/03 a 25/10/1996. Piracicaba/SP.........44

8. Valores médios de temperaturas em masas fecais de quatro idades diferentes (MF1, MF2, MF3 e MF4), e em ambiente de pastagem, durante $O$ período de 01/03 a 25/10/1996. Piracicaba/sP. ......................... 46

9. Valores médios de temperaturas $\left({ }^{\circ} \mathrm{C}\right)$ na superfície, interior e interface de massas fecais de quatro idades distintas (MF1, MF2, MF3 e MF4), e a um metro de altura e ao nível do solo, durante $O$ período de 01/03 a 25/10/1996. Piracicaba/sp. ........................ 48 
10. Coeficiente de determinação $\left(R^{2}\right)$ e probabilidade entre temperatura média do ambiente de pastagem e de massas fecais de quatro idades distintas (MF1, MF2, MF3 e MF4), durante o período de 01/03 a 25/10/1996. Piracicaba/SP ..58

11. Período de desenvolvimento da fase de ovo a adulto de $H$. irritans, mantido em diferentes temperaturas $\left({ }^{\circ} \mathrm{C}\right)$ (MELVIN \& BECK, 1931; HONER et al. 1990) ...............62

12. Limite térmico inferior de desenvovimento (Tb), constante térmica $(K)$ e coeficiente de determinação $\left(\mathrm{R}^{2}\right)$ de $H$.

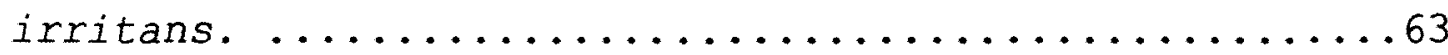

13. Médias mensais de temperaturas $\left({ }^{0} \mathrm{C}\right)$ em quatro distintas idades de massas fecais (MF1, MF2, MF3 e MF4), e dias necessários para o desenvolvimento de uma geração de $H$. irritans, durante o período de 01/03 a 25/10/1996. Piracicaba/sP. .........................65

14. Médias mensais de temperaturas $\left({ }^{0} \mathrm{C}\right)$ em três idades distintas de massas fecais (MF1, MF2 e MF3), a cinco centímetros de profundidade no solo, e dias necessários para o desenvolvimento de uma geração de $H$. irritans, durante o período de 09/08 a 25/10/1996. Piracicaba/SP ..66 


\section{LISTA DE FIGURAS}

1. Armadilha "pitfall" com um volume de massa fecal funcionando como atrativo, e copo plástico com água e detergente para

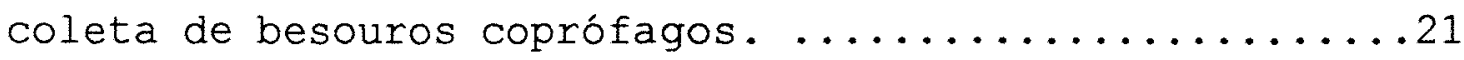

2. Termopar modelo TDB 40C12 utilizado para leituras de temperaturas na superfície do solo em áreas de pastagem (A), Eucalyptus sp. com sub-bosque (B) e massa fecal de

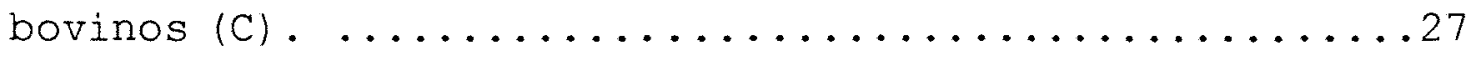

3. Capturas mensais de Dichotomius anaglypticus, Aphodius pseudolividus e Ataenius sp.2, em armadilha "pitfall", durante o periodo de $01 / 03$ a 25/10/1996. Piracicaba/SP. .33

4. Dados mensais de temperaturas máxima, média e mínima $\left({ }^{0} \mathrm{C}\right)$, precipitação pluvial (PPT) e umidade relativa do ar (UR), durante o período de 01/03 a 25/10/1996. Piracicaba/SP...34 
5. Valores mensais de temperaturas na superfície do solo e a um metro de altura nas áreas de pastagens e Eucalyptus sp. com sub-bosque, durante o período de 01/03 a 25/10/1996. Piracicaba/sP. ......................... 43

6. Valores mensais de temperaturas na superficie, interior e interface de massas fecais de idades 1 e 2, durante 0 período de 01/03 a 25/10/1996. Piracicaba/sP. .........49

7. Valores mensais de temperaturas na superficie, interior e interface de massas fecais de idades 3 e 4 , durante 0 período de $01 / 03$ a $25 / 10 / 1996 \ldots \ldots \ldots \ldots \ldots \ldots \ldots \ldots$

8. Temperaturas médias na superfície, interior e interface de massas fecais de idades 1 e 2, no dia 05/04/1996, às 8:00 e $14: 00$ h. Piracicaba/sp. ...................... 52

9. Temperaturas médias na superfície, interior e interface de massas fecais de idades 3 e 4, no dia 05/04/1996, ás 8:00 e 14:00 h. Piracicaba/sp. ......................

10. Temperaturas médias na superfície, interior e interface de massas fecais de idades 1 e 2, no dia 06/06/1996, às 8:00, 12:00 e 16:00 h. Piracicaba/sP. ................ 54 
11. Temperatura médias na superfície, interior e interface de massas fecais de idades 3 e 4, no dia 06/06/1996, às 8:00, $12: 00$ e 16:00 h. Piracicaba/sP. .................55

12. Temperaturas médias na superfície do solo e a um metro de altura, na área de pastagem às 8:00 e 14:00 h e as 8:00, 12:00 e 16:00 h nos dias 05/04 e 06/06/1996 respectivamente. Piracicaba/SP. ...............56

13. Temperaturas médias reais e estimadas de massas fecais de idades 1 e 2, durante o período de 01/03 a 25/10/1996.

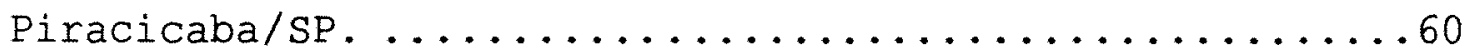

14. Temperaturas médias reais e estimadas de massas fecais de idades 3 e 4, durante o período de 01/03 a 25/10/1996. Piracicaba/sP. .......................61

15. Curva de velocidade de desenvolvimento de $H$. irritans em diferentes temperaturas. ..................64 


\title{
OCORRÊNCIA DE BESOUROS COPRÓFAGOS E AVALIAÇÕES MICROCLIMÁTICAS EM MASSAS EECAIS DE BOVINOS, VISANDO AO CONTROLE BIOLÓGICO DE Haematobia irritans (LINNÉ, 1758) (DIPTERA; MUSCIDAE) EM PIRACICABA/SP
}

\author{
Autor: SÉRGIO ROBERTO RODRIGUES \\ Orientador: Prof. Dr. LUIS CARLOS MARCHINI
}

\section{RESUMO}

Utilizando-se de armadilhas "pitfall" iscadas com massa fecal fresca de bovinos, instaladas em áreas de pastagem e Eucalyptus sp. com sub-bosque circundado por mata nativa, realizou-se a coleta de besouros coprófagos durante o período de 01/03/1996 a 25/10/1996, em Piracicaba/SP. Tomou-se leituras de temperatura nos dois ambientes, bem como em massas fecais de quatro diferentes idades presentes na área de pastagem. Na área de pastagem Dichotomius anaglypticus é a principal responsável pela remoção de massas fecais. Foram desenvolvidas fórmulas matemáticas que possibilitam prever as temperaturas em massas fecais de bovinos e o desenvolvimento de Haematobia irritans. 


\title{
OCCURRENCE OF COPROPHAGOUS BEETLES AND MICROCLIMATIC EVALUATIONS ON COW DUNG AIMING AT THE BIOLOGICAI CONTROL OF Haematobia irritans (LINNÉ, 1758) (DIPTERA; MUSCIDAE) IN PIRACICABA, STATE OF SÃO PAULO
}

\author{
Author: SÉRGIO ROBERTO RODRIGUES \\ Adviser: Dr. IUIS CARLOS MARCHINI
}

\section{SUMMARY}

Coprophagous beetles were collected by using pitfall traps baited with fresh cow dung and set in areas of pasture and Eucalyptus sp. plantations with underbrush and surrounded by native woods. The experiment was set in Piracicaba, state of São Paulo, from March 1st to october 25th, 1996. The temperatures of these two environments as well as of the cow dungs of four different ages present in the pasture area weekly taken. Dichotomius anaglypticus was observed to be the species responsible for the removal of the cow dung masses. To facilitate the control of the horn fly, mathematical formulae were developped to forecast the temperatures of the cow dung masses and the development of Haematobia irritans. 


\section{INTRODUÇÃO}

No Brasil a atividade pecuária é composta por cerca de 151 milhões de bovinos (FAO, 1995), que representa importante fonte de renda para as regiões que desenvolvem essa atividade, seja pela produção de alimentos como carne e leite, ou pela exploração de subprodutos como couro e outros derivados que têm grande interesse para industrias em geral.

Existem vários fatores que interferem e, dependendo da situação, limitam a atividade pecuária, os quais estão incluidos os aspectos de sanidade animal como os carrapatos, helmintos e diversas espécies de moscas, que estão associados à bovinocultura nacional.

Recentemente, uma nova espécie foi adicionada a esta relação, que é a mosca-dos-chifres (Haematobia irritans), atualmente ocupando grande extensão do território nacional, causando sérias preocupações aos pecuaristas, devido aos prejuízos que podem ocasionar (HONER et al., 1990).

os danos causados pela mosca-dos-chifres podem ser sérios, indo desde fazer $\circ$ animal se alimentar menos a até torná-lo mais susceptível a uma série de doenças e parasitoses, resultando em acentuada perda de peso e diminuição na produção (HILLERTON et al., 1990).

A sua erradicação é praticamente impossível, e o uso de produtos químicos apresenta uma série de restrições, indo desde o acúmulo de resíduos tóxicos no animal à seleção de raças resistentes da mosca aos produtos químicos.

A fase imatura da mosca desenvolve-se em massas fecais de bovinos, que podem permanecer de 8 a 9 meses no campo sobre as pastagens, se não forem removidas, sendo ainda consideradas como uma unidade ecológica (ALVES, 1977; LUMARET 
\& KIRK, 1987).

A única técnica econômica de remoção das massas fecais do campo, é pelo trabalho de besouros coprófagos, que podem localizar, incorporar e/ou desestruturar rapidamente, melhorando assim as propriedades físicas e químicas do solo, constituindo-se ainda como uma alternativa no controle de $H$. irritans.

- presente trabalho tem por objetivos conhecer as espécies de besouros que ocorrem em área de pastagem e de Eucalyptus sp. com sub-bosque circundado por mata nativa, identificar as espécies mais eficientes na remoção de massas fecais, e verificar o microclima ocorrente em massas fecais de bovinos com vistas ao controle biológico da mosca-dos-chifres (H. irritans). 


\section{REVISÃO DE LITERATURA}

\subsection{Mosca-dos-chifres (Haematobia irritans)}

\subsubsection{Dados biológicos}

Das várias espécies de dipteros de importância veterinária associadas ao rebanho bovino no Brasil, a mais recente introduzida é conhecida como mosca-dos-chifres ( $H$. irritans).

A fase adulta desse díptero apresenta aproximadamente de 2 a $4 \mathrm{~mm}$ de comprimento e apresenta hábito alimentar hematófago (SAUERESSIG, 1992), sendo considerado parasito obrigatório que permanece dia e noite sobre o bovino, e em laboratório criado em dieta artificial pode sobreviver por 28 dias (MACLINTOCK \& DEPNER, 1954).

A fêmea faz postura em massas fecais de bovinos, onde as larvas se desenvolvem. Segundo GUIMARÃEs (1990), os ovos são depositados individualmente, sendo que cada fêmea realiza cerca de 15 posturas durante seu ciclo de vida, tendo preferência para oviposição nas áreas laterais da massa fecal.

Durante um periodo de 6,6 dias um adulto oviposita cerca de 78 ovos (KRAFSUR \& ERNST, 1986).

Os ovos são colocados em pequenos grupos de quatro a seis, sendo que os mesmos exigem uma alta umidade relativa, e têm período de incubação de aproximadamente 24 horas. Para o período de incubação encontrou-se duração de 19 horas e 35 minutos e 14 horas e 25 minutos, quando mantidos nas temperaturas de 25 e $30^{\circ} \mathrm{C}$, respectivamente (MELVIN \& BECK, 1931). 
Uma vez eclodida, a larva que vive apenas em fezes de bovinos (MACLINTOCK \& DEPNER, 1954), penetra na massa fecal onde irá se alimentar, procurando a umidade necessária à sua sobrevivência e desenvolvimento. O período larval tem duração média de 5 dias, após o qual forma-se a pupa. A pupação ocorre na massa fecal ou próxima ao solo, dependendo das condições de umidade. o período pupal é de cerca de 5 dias, quando emerge o adulto. A cópula ocorre de 2 a 3 dias após a sua emergência, durante a noite, e normalmente sobre o animal (FERREIRA, s.d.).

As larvas podem ainda transformar-se em pupas no solo, abaixo da massa fecal (LINDQUIST, 1936). O período compreendido entre a fase de ovo, larva e pupa dura cerca de 9,94 dias (MELVIN \& BECK, 1931).

\subsubsection{Danos e alternativas para controle}

HILLERTON et al. (1990) citam que, o aninal picado, torna-se irritado e inquieto, provocando redução na alimentação e ferimentos devido as tentativas de se livrar do inseto, resultando em infeç̧ões sérias. Estes ferimentos podem atrair outros tipos de moscas, tais como Cochliomyia hominivorax (mosca-das-bicheiras) e Hydrotaea irritans, agravando-os.

HARRIS et al. (1974) observaram em média 38,4 picadas por fêmea ao dia, com um total de 163 minutos diários de alimentação, onde ingere cerca de 14,6 microgramas de sangue, enquanto que o macho pica cerca de 24 vezes ao dia.

Isto permite uma estimativa de perda de sangue por animal ao dia de $7 \mathrm{ml}$ ou uma perda teórica anual de 2,6 litros de sangue. Neste caso a perda anual de peso do animal equivaleria a 40 quilogramas, dos quais somente 2 ou 3 quilogramas seriam resultantes da perda de sangue ingerido pela mosca, enquanto que o restante seria atribuido ao efeito 
estressante ocasionado pelo díptero (HONER \& GOMES, 1990).

A espécie $H$. irritans tem preferência por bovinos de pelagem escura (COLLARES \& LEITE, 1992), os animais atacados ficam irritados, e alimentam-se mal o que leva a uma diminuição na produção de carne e leite (SAUERESSIG, 1992).

Desde 1980 os técnicos do Centro Nacional de Pesquisas do Gado de Corte - EMBRAPA de Campo Grande/MS, têm conhecimento da existência de $H$. irritans atacando o rebanho bovino em propriedades rurais e abatedouros no município de Boa Vista, Roraima (VALÉRIO \& GUIMARÃEs, 1983), sendo esse provavelmente o Estado por onde a mosca entrou no país.

Acredita-se que a mosca-dos-chifres seja proveniente da Guiana, Venezuela, Colômbia ou Chile, pois nesses paises já havia registros de sua ocorrência (VALÉRIO, 1985).

Graças a uma fiscalização ineficaz quanto ao trânsito de animais de uma região para outra, e a característica intrínsica da mosca, que apresenta uma taxa de expansão linear anual de 100 a 140 quilômetros (HONER et al., 1988), este inseto está presente atualmente em $2 / 3$ do território nacional (GONÇALVES, 1990).

No Estado de São Paulo a mosca-dos-chifres é citada desde 1990 (GRISI \& SCOTT, 1991), tendo sido localizados focos em várias regiões, atribuindo-se sua introdução, a partir da região noroeste do Estado de Goiás (FERREIRA, s.d.).

Medidas de controle para este díptero fazem-se necessárias, face aos prejuízos evidentes que ocasionam.

Um modo eficiênte de combatê-la é através do uso de produtos químicos como inseticidas a base de piretróides (SCOTT \& GRISI, 1991; MWANGALA \& GALLOWAY, 1993).

Apesar de apresentar efeito imediato, o uso de produtos químicos para o controle desse díptero apresenta inconvenientes, como a possibilidade de seleção de raças resistentes aos inseticidas.

Em 1983 apareceu nos Estados Unidos o primeiro caso de resistência de $H$. irritans, aos piretróides usados para seu 
controle (WILLIANS, 1991).

Devido ao mecanismo de resistência apresentado por esse díptero aos produtos químicos utilizados, uma alternativa ao controle seria o uso de agentes biológicos para combater a mosca.

Destacam-se como alternativas no controle biológico os coleópteros da familia scarabaeidae, onde há vários representantes que se caracterizam por desestruturar/incorporar as massas fecais dos bovinos. Ao enterrarem as massas fecais no solo, estarão enterrando também, ovos e larvas de mosca-doschifres, ou ainda competindo por alimento, e alterando o local de desenvolvimento das larvas. Também ao desestruturar e enterrar estas fezes, estarão contribuindo para o aumento da fertilidade do solo e recuperação da área de pastagem sob as fezes.

\subsection{Besouros coprófagos}

\subsubsection{Distribuição de espécies nas regiões do Brasil}

Os besouros coprófagos, pertencem à família Scarabaeidae, da qual estima-se existirem mais de $20 \mathrm{mil}$ espécies no mundo (RODRIGUES, 1985; FINCHER, 1991).

Fincher ${ }^{1}$, citado por GALBIATI et al. (1995) comparou a fauna coprófaga da América do Norte e do Sul, revelando que 1.137 espécies são descritas nas Américas e dessas, 945 ocorrem na América do Sul. Já na África são encontradas cerca de 2.000 espécies.

1 FINCHER, G.T. The potencial value of dung beetles in pasture ecossystems. Journal Aust. Inst. Georgia Entomol. Soc. V.16, n.2, p.316-333, 1981. 
Apesar de mundialmente distribuidos, os diferentes microclimas encontrados influem na distribuição das espécies. No Brasil não se sabe ao certo o número de espécies existentes, entretanto, alguns trabalhos foram feitos no sentido de localizar e relacionar espécies ocorrentes.

Para a região Sul do país, coletas foram realizadas no município de Santa Maria/RS, encontrando-se 19 espécies de besouros coprófagos em área de pastagem (LINK, 1976); em Jaraguá do Sul/SC, 8 espécies (FLECHTMANN \& RODRIGUES, 1995); em Mandirituba/PR, 14 espécies (STUMPF, 1986); e em Irati/PR, 18 espécies (RODRIGUES \& FLECHTMANN, 1995b).

LANGE (1947) relaciona ainda 116 espécies de Scarabaeidae copro-necrófagos que ocorrem no Estado do Paraná.

$\mathrm{Na}$ região Sudeste do país, 15 espécies foram encontradas em Ilha Solteira/SP (FLECHTMANN et al., 1995c); cerca de 22 espécies em Piracicaba/SP (ALVES, 1977; RODRIGUES \& MARCHINI, 1996); 29 espécies no município de Pereira Barreto/SP (RODRIGUES \& FLECHTMANN, 1995a); cerca de 11 espécies em São Carlos/SP (OLIVEIRA et al., 1996); 5 espécies em Jaboticabal/SP (RODRIGUES et al., 1990); e em Viçosa/MG foram coletadas 42 espécies (LOUZADA, 1996).

Para a região Centro Oeste do país, 43 espécies foram registradas ocorrendo em área de pasto, mata ciliar e transição em Selvíria/MS (RODRIGUES \& FLECHTMANN, 1993); 41 espécies em Campo Grande/MS (GOMES et al., 1995); e 20 espécies na cordilheira do Pantanal de Miranda/MS (LOUZADA et al., 1996).

Na região Norte do país é registrado a ocorrência de 58 espécies em Manaus/AM (KLEIN, 1989).

Na região Nordeste do país, foi realizado a coleta em quatro diferentes ambientes na região de Feira de Santana/BA, encontrando-se 25 espécies (LOPES et al., 1996).

Algumas revisões sobre grupos específicos foram feitas, revelando a existência de diferentes espécies em gêneros distintos. LUEDERWALDT (1929; 1931) relata a ocorrência de 57 espécies de besouros coprófagos do gênero Dichotomius e 
17 do gênero ontherus. PESSOA (1934; 1935) relaciona 37 espécies do gênero Phanaeus e 3 do gênero Taurocopris. D'OLSOUFIEFF (1924) relaciona duas espécies do gênero Gromphas, e várias do gênero phanaeus ocorrendo no Brasil.

O gênero Pedaridium possui 8 espécies que ocorrem em vários Estados (FERREIRA \& GALILEO, 1993); para o gênero Deltochilum PAULIAN (1939) registrou 7 espécies em várias regiões, e do gênero Eurysternus encontrou-se 13 espécies distribuidas nas várias regiões do Brasil (JESSOP, 1985).

Apesar dos trabalhos já realizados no assunto pode-se dizer que, muitas espécies que ocorrem no Brasil ainda não são conhecidas, havendo portanto a necessidade de realizar estudos em várias outras regiões do país.

\subsubsection{Influência da vegetação na distribuição das espécies}

A ocorrência das espécies de besouros coprófagos nos vários ambientes, pode estar relacionada a alguns fatores. RIDSDILL-SMITH (1986) cita temperatura, precipitação pluvial, condições de solo e densidade de besouros como fatores influentes, enquanto KEY (1982) relata a altitude local e LUMARET \& KIRK (1987) acrescentam a vegetação e luminosidade como fatores determinantes da riqueza da comunidade de besouros coprófagos.

HALFFTER et al. (1992) comentam que dentre os fatores ambientais o tipo de vegetação é o mais importante para os besouros coprófagos, sendo este o fator determinante na distribuição das espécies. Quando a agricultura ou áreas de pastagens são criadas, severos micro-macroclimas são produzidos aumentando a média da temperatura do ar e do solo, adaptando algumas novas espécies a esse novo cenário ecológico, mas fazendo desaparecer outras. O resultado final é uma profunda 
mudança na estrutura e composição da comunidade original, uma mudança que pode ser irreversível.

Em regiões tropicais é comum encontrar distintas diferenças na composição de espécies em florestas e áreas desmatadas (HOWDEN \& NEALIS, 1975; PECK \& FORSYTH, 1982; HALFFTER, 1991b).

Em alguns ambientes pode-se verificar diferenças na quantidade de insetos. LUMARET \& KIRK (1987) encontraram um total de 25 a 30 vezes mais biomassa de besouros coprófagos em áreas abertas quando comparada com área de floresta.

Em Manaus/AM, KLEIN (1989) registrou em fragmento de floresta, menor riqueza de espécies, mais espécies raras e esparsas populações de besouros coprófagos em relação a floresta contínua. O autor ainda relatou que a floresta ao ser fragmentada, sofre alterações microclimáticas, diminuindo, assim, a fauna de mamíferos e pássaros e consequentemente a oferta de alimento, refletindo na diminuição da fauna de besouros coprófagos e necrófagos, o que pode alterar a incidência de parasitos e doenças em vertebrados. Com o desmatamento e formação de fragmentos de florestas e clareiras poucas são as espécies que podem adaptar-se a esse novo ambiente, dentre elas encontrou-se Glaphyrocanthon sp..

HALFFTER et al. (1992) estudando três áreas distintas encontraram 27 espécies de besouros coprófagos em floresta, 11 em margem de floresta e 5 em florestas modificadas, comprovando as diferenças na comunidade coprófaga em ambientes distintos. As espécies encontradas nas margens tem grande chance de adaptarem-se a novos ambientes. O desmatamento causa queda na diversidade, e a sobrevivência das espécies depende da preservação das árvores e partes da floresta original. Na floresta as espécies dominantes foram Deltochilum gibbosun $(27,27 \%)$, Copris laeviceps $(17,75 \%)$ e Deltochilum pseudoparile $(15,87 \%)$ e na margem da floresta Copris laeviceps $(26,85 \%)$, Canthon cyanellus cyanellus $(12,85 \%)$ e Onthophagus batesi $(11,43 \%)$ foram dominantes. Na área modificada Copris laeviceps 
$(68,77 \%)$ e Canthon viridis leechi $(25,60 \%)$ foram predominantes.

Ao estudar a fauna coprófaga presente em habitats diferentes, BAZ (1988) encontrou 30 espécies distribuidas diferentemente conforme a densidade e altura da vegetação. As espécies Onthophagus fracticornis, O. similis e Aphodius spp., são associadas exclusivamente a área de pastagem, enquanto que Aphodius frigidus prefere área de floresta.

Alguns grupos de besouros coprófagos podem apresentar preferência por determinados ambientes, como Ateuchus que é primordialmente sílvicola e de hábito noturno (KOHLMANN, 1984).

\subsubsection{Aspectos biológicos}

Os vários grupos de besouros coprófagos existentes, desenvolveram formas distintas de utilizar a massa fecal. A variação existente no modo como se alimentam, trabalham e fazem a oviposição, levou vários pesquisadores a propor as seguintes divisões para estes grupos (WATERHOUSE, 1974; HEINRICH \& BARTHOLOMEW， 1979; RODRIGUES, 1989):

- telecoprídeos: besouros que apresentam hábito de construir bolas de excrementos, que são roladas para locais distantes das massas fecais e enterradas em galerias previamente construídas; são os típicos "rola-bostas", representados por espécies do gênero Canthon;

- paracoprídeos: besouros mais comuns, com cerca de 80\% das espécies, caracterizando-se por construir galerias proximamente ou abaixo da massa fecal, em profundidade que varia de 0,10 a $1,00 \mathrm{~m}$, dependendo das condições do solo; são representados por espécies do gênero Dichotomius, ontherus etc. ;

- endocoprídeos: besouros que penetram na massa fecal e aí permanecem, somente abandonando-a quando as condições são 
desfavoráveis; são representados por espécies do gênero Aphodius, Ataenius, Eurysternus etc..

Para utilizarem a massa fecal, os besouros coprófagos inicialmente a localizam, através de estímulos olfativos, pousando normalmente a alguns metros da massa fecal e caminham posteriormente a esta (MOHR, 1943; HEINRICK \& BARTHOLOMEW, 1979).

MOHR (1943) considerou os Scarabaeidae um dos primeiros a aparecer nas massas fecais, inclusive antes dos insetos predadores, 0 que foi confirmado parcialmente por HANSKI (1980), que estimou que a maioria destes ( 88 a $100 \%$ do total) chegam as massas nos dois primeiros dias. Já KLEIN (1989) considerou-os como sendo os primeiros decompositores de fezes na comunidade florestal amazônica.

$\mathrm{Na}$ Dinamarca, constatou-se que Aphodius rufipes colonizou a massa fecal quase imediatamente após a mesma ser excretada, permanecendo nesta por 4 a 6 dias. Massas fecais depositadas mais no início da noite tinham mais besouros que as colocadas na manhã do mesmo dia, evidenciando a importância do horário em que esta é excretada (HOLTER, 1979).

Dichotomius anaglypticus é atraída à massa fecal por estímulos olfativos, voando várias vezes em círculo sobre a mesma, diminuindo paulatinamente a distância, até finalmente pousar num ponto próximo à massa (ALVES, 1977). O autor comparou o pouso deste como uma pequena queda livre, sendo a massa fecal geralmente não atingida. Após o pouso, caminham rapidamente em direção à massa, introduzindo-se nesta.

No Brasil, os besouros são encontrados em plena atividade logo após a entrada de animais na área, no início da estação chuvosa (RODRIGUES, 1985). Ao estudarem a fauna coprófaga na região de Selvíria/MS, encontraram maior atividade na estação chuvosa do ano, e os besouros de maior biomassa foram os responsáveis pela desestruturação/incorporação das massas fecais (FLECHTMANN et al., 1995a). 
MERRITT \& ANDERSON (1977) ressaltaram a importância do fator biomassa da espécie no sucesso da ação dos besouros ao enterrar as massas fecais, sobrepondo-se mesmo ao número de indivíduos existentes, refletindo, assim, na taxa de degradação da massa.

Os besouros coprófagos normalmente incorporam a massa fecal para alimentarem-se ou ovipositarem, e a oviposição é variável dependendo da espécie em questão. Um ovo apenas é depositado para cada pêra de nidificação no ninho para Canthon Iugubris (MYRCHA \& ANDRZEJEWSKA, 1984). Há espécies que fazem a postura de grande número de ovos, como onthophagus binodis, onde cada fêmea chega a por 50 ovos (RIDSDILL-SMITH, 1984).

Estes ovos darão origem a larvas, que passam sempre por 3 instares larvais (HALFFTER \& MATTHEWS, 1966), e a maioria das espécies passa esta fase de desenvolvimento no solo, alimentando-se de bolas de massas fecais armazenadas. As espécies Onthophagus binodis e O. alexis (RIDSDILL-SMITH, 1984) apresentam 2 gerações por ano, enquanto que Onthophagus ferox (RIDSDILL-SMITH, 1984), Scarabaeus laticollis (KIRK \& WALLACE, 1990), apresentam somente uma.

$\mathrm{Na}$ espécie Onthophagus gazella encontraram que as combinações de $2,4,8,16$ e 32 casais produziram respectivamente, $44,66,41,36$ e 30 pêras de nidificação, mostrando que a competição intraespecífica diminui o número de ovos depositados por fêmea (LEE \& PENG, 1982).

Para a espécie Dichotomius anaglypticus, encontrou-se que a fêmea põe de 1 a 2 ovos por ano e a eclosão ocorre após 15 a 18 dias. A fase larval dá-se nas denominadas pêras de nidificação, e esta fase dura em torno de 70 a 85 dias, a de pré-pupa 95 dias e a da pupa, 85 dias. A longevidade do adulto, em laboratório, foi de 100 dias (ALVES, 1977; ALVES \& NAKANO, 1978).

Para algumas espécies do gênero Phanaeus, observou-se que constroem ninhos com profundidades de 15 a 50 centimetros, onde formam uma pêra de nidificação no final do canal. Dentro 
da pêra de nidificação as fêmeas depositam um ovo que pode apresentar período de incubação de cerca de 17 dias, e a fase larval pode durar cerca de 60 dias (PESSOA, 1934).

Existe uma característica nos Scarabaeinae que é a existência do cuidado com a fase jovem, sendo esse um requisito indispensável para o comportamento subsocial. Esse cuidado com a prole é para evitar a ação de fungos e reparar fissuras nas pêras de nidificação, e para evitar ataque de insetos intrusos (HALFFTER, 1991a).

Phanaeus daphinis e $P$. mexicanus apresentam $\circ$ comportamento de macho e fêmea trabalharem juntos na construção e armazenamento da massa fecal, sendo esse um exemplo de um inseto sub social (HALFFTER et al., 1974).

Em Phanaeus difformis, encontrou-se que a fase de ovo a adulto tem a duração de 6 a 12 meses, e os adultos apresentam longevidade de 473 dias. Três casais produziram 20, 33 e 52 pêras de nidificação e em cada pêra encontrava-se um ovo (BLUME $\& A G A, 1976)$.

Para a espécie Eurysternus caribaeus, observou-se que a cópula dura de 65 a 80 minutos, e a fêmea constrói de 2 a 6 pêras de nidificação acondicionando um ovo em cada, e ainda cuida das pêras por ela construida (HALFFTER et al., 1980). Ao estudar a biologia de Canthon virens, encontrou-se de 2 a 3 ovos por ninho, o período larval foi de 26 dias, o pupal de 23 dias, sendo que a fêmea cuida das pêras de nidificação durante o desenvolvimento da fase jovem (RINALD et al., 1993).

Em Ateuchus apicatus encontrou-se ninhos a cerca de $8 \mathrm{~cm}$ de profundidade, e de uma a seis pêras de nidificação com um ovo cada. O período de incubação dos ovos é de cerca de 1516 dias, o período larval de 108, o pupal de 23 e os adultos apresentaram longevidade aproximada de 60 dias em laboratório (STUMPF et al., 1986a). Para Ateuchus mutilatus, encontrou-se que este constrói ninhos a cerca de $10 \mathrm{~cm}$ de profundidade, onde armazena a massa fecal, e constrói de quatro a cinco pêras de 
nidificação e em cada pêra deposita um ovo. o período de incubação é de 15,06 dias, o período larval de 104,68, o pupal de 26 e os adultos apresentaram longevidade média de 90 dias (STUMPF et al., 1986b).

Em Typhaeus typhoeus encontrou-se que a cópula tem duração de 3 a 20 minutos, e o cilo de vida é de dois anos (BRUSSAARD, 1983). Em Euoniticellus intermedius, encontrou-se que macho e fêmea constroem juntos o canal de nidificação, a uma profundidade de 7 a $15 \mathrm{~cm}$, e o período de incubação dos ovos a $33,4{ }^{0} \mathrm{C}$ e $19,4{ }^{\circ} \mathrm{C}$ é de 2 e 10 dias, respectivamente, e os adultos têm longevidade de 41,3 e 83,8 dias a 19,4 e $36^{\circ} \mathrm{C}$ (BLUME, 1984).

Estudando a biologia de Heliocopris dilloni KINGSTON \& COE (1977), verificaram que este constrói ninhos de 30 a 120 cm de profundidade, a fêmea põe cerca de sete ovos, e de ovo a adulto apresenta duração de 23 semanas.

O desenvolvimento de ovo a adulto de onitis caffer na temperatura de $25^{\circ} \mathrm{C}$, teve duração de 24,7 a 29,4 semanas, ocorrendo ainda a diapausa facultativa na larva de terceiro instar (EDWARDS, 1986).

Para atração entre os sexos pode ocorrer a presença de feromônios sexuais, como observado para Typhaeus typhoeus (BRUSSAARD, 1983) e Kheper nigroaeneus (EDWARDS \& ASCHENBORN, 1988).

\subsubsection{Controle de moscas e helmintos}

Em alguns paises como Estados Unidos e Austrália, houve a introdução de moscas hematófagas que causam grandes prejuízos ao rebanho bovino, e esses foram os primeiros paises a realizar estudos com besouros coprófagos visando ao controle desses agentes (DOUBE, 1986; HONER et al., 1990).

outro grande problema para a pecuária, são os 
helmintos gastrointestinais que debilitam os animais levando a diminuição na produção de leite e carne. Poucos trabalhos foram realizados onde avaliou-se a ação dos besouros coprófagos no controle desses.

Segundo BRYAN (1973) mesmo em número baixo, os besouros coprófagos reduzem o número de nematóides devido a aeração que ocasionam nas massas fecais.

FINCHER (1973) ao comparar três áreas onde manteve a população natural de besouros coprófagos, com área onde foi aumentada artificialmente e outra onde retiraram os besouros. Encontrou na terceira área 14,7 vezes mais larvas de Ostertagia ostertagia do que onde a população foi aumentada, e na área com população natural havia 3,7 vezes mais larvas do que a área com aumento artificial. Ao repetir o experimento (FINCHER, 1975) encontrou-se 9,4 vezes menos larvas de helmintos no trato digestivo dos bovinos, quando comparado com a área testemunha sem besouros, e na área com população normal de besouros, 2, 7 vezes mais helmintos do que naquela onde aumentou a população de besouros.

Na Austrália, foi constatada a redução de $50 \%$ de helmintos gastrointestinais em massas fecais, onde Onthophagus gazella atuou por 3 dias, em comparação com a testemunha que após 8 dias, havia 19 vezes mais helmintos (BRYAN, 1976).

GRONVOLD et al. (1992) avaliaram a ação de Diastellopalpus quinquedens sobre Cooperia $\mathrm{sp}$. e encontraram que a atividade de incorporar massa fecal, reduz grandemente a dispersão de larva de terceiro ínstar, reduzindo, assim, a transmissão de nematóides parasitos de bovinos.

os besouros coprófagos atuam no controle de espécies ecto e endoparasitos de gado que dependem das massas fecais para completarem seu ciclo de vida. A população de moscas pode ser bastante reduzida, quando as fezes são ingeridas ou enterradas dentro de 1 a 2 dias após terem sido excretadas (RODRIGUES, 1985).

DOUBE et al. (1988) trabalhando em campo com 
Haematobia thirouxi potans verificaram uma mortalidade de 84,3, 92,8 e 97,6\% em três diferentes localidades na África, e de 66,7\% em Haematobia irritans exigua na Austrália, ocasionada por besouros coprófagos. O tamanho da mosca fêmea é diretamente proporcional à sua capacidade de reprodução, sendo verificado redução na população e no tamanho da cápsula cefálica dos adultos emergentes. A sobrevivência média de ovo a adulto de mosca em massas fecais que sofreram a ação de besouros coprófagos foi menor do que em fezes controladas, indicando que a fauna das fezes causa extensiva mortalidade.

Trabalhando-se com Catharsius tricornutus, visando ao controle de $H$. thirouxi potans, encontrou-se diminuição na sobrevivência da mosca na presença do besouro coprófago. A sobrevivência da mosca diminui com o aumento dos níveis de massa fecal incorporada. Os ovos e larvas podem morrer após a atividade de besouros coprófagos (DOUBE \& MOOLA, 1988).

Musca autumnalis na fase adulta é praga de bovinos na América do Norte e suas larvas aparecem nas fezes que não são incorporadas por besouros coprófagos. Ao utilizar onthophagus taurus para incorporar massa fecal com larvas desta mosca, encontrou-se que ao aumentar a densidade do besouro, ocorreu diminuição na sobrevivência e no tamanho das moscas emergentes. Porém, Onitis alexis ao ter sua densidade aumentada dentro da massa fecal não afetou o desenvolvimento da mosca (MOON et al., 1980).

Onthophagus gazella foi estudado e avaliado quanto ao potencial de controle de Musca vetustissima, encontrou-se que as massas fecais são incorporadas dentro de 30 a 40 horas após a colonização por essa espécie, e que a velocidade com que as fezes são enterradas é tida como um fator crítico no controle da mosca (BORNEMISSZA, 1970).

Estudos conduzidos em laboratório por RIDSDILL-SMITH (1988), com Onitis alexis coletado em outubro e dezembro e Onthophagus binodis coletado em janeiro, reduziram em 4\% a sobrevivência de $M$. vetustissina. $O$. binodis coletado em março 
e outubro e Onthophagus ferox coletado em maio e dezembro reduziram em $32 \%$ a sobrevivência da mosca.

HUGHES et al. (1978) verificaram que a sobrevivência de $M$. vetustissima diminuiu com 0 aumento da população de Euoniticellus intermedius. Os resultados sugeriram que um distúrbio nas fezes foi importante causa de mortalidade de moscas. A pior qualidade das fezes tem importância na sobrevivência de moscas. Alta densidade de besouros (>150/litro de massa fecal) também tem efeito na supressão do número de moscas.

RIDSDILL-SMITH \& MATTHIESSEN (1984) trabalharam com M. vetustissima, e deixaram a mesma ovipositar em massas fecais protegendo-a da ação de besouros coprófagos enquanto, que outras massas foram expostas a ação de onthophagus ferox e Onitis alexis. Encontraram que fezes protegidas tiveram 1019 moscas emergentes e as massas expostas a ação de o. ferox apenas 679 moscas. Para 0 . alexis, fezes que sofreram ação de incorporação apresentaram 14 moscas emergentes e fezes testemunha 33 moscas.

A espécie Onthophagus binodis na densidade de 120 besouros por massa fecal, produz mortalidade de $12 \%$ de ovos, 11\% de larvas jovens, mas não afeta larvas velhas de $M$. vetustissima (RIDSDILL-SMITH \& HAYLES, 1987).

Além do controle na fase larval, as moscas podem ser controladas na fase de ovo, através do enterramento destes por besouros coprófagos (EDWARDS \& ASCHENBORN, 1987).

MERRITT \& ANDERSON (1977), obtiveram uma redução na densidade populacional de $H$. irritans e M. autumnalis com a utilização do besouro endocoprídeo Aphodius fimetarius de pequena biomassa.

Usando 0 aumento da densidade populacional de 0 . binodis e O. alexis, RIDSDILL-SMITH \& HAYLES (1990) obtiveram um aumento na mortalidade de larvas de $M$. vetustissima, principalmente para as larvas mais velhas. 


\subsection{Estudo da massa fecal}

As massas fecais são continuamente depositadas nas pastagens, haja vista que um bovino produz cerca de 10 massas fecais por dia e estas ocupam uma área de $600 \mathrm{~cm}^{2}$ (RIDSDILLSMITH \& MATTHIESSEN, 1981). Se não forem incorporadas pelos besouros coprófagos, podem permanecer de 8 a 9 meses no campo (ALVES, 1976).

Como a massa fecal pode permanecer por um certo período de tempo na superfície de áreas de pastagens, forma-se aí um local de abrigo para vários insetos, podendo formar um microclima distinto do ambiente.

Após ser depositada a massa fecal começa a perder umidade, e em função dela foi classificada por AVILA \& FERNÁNDEZ-SIGLER (1988), como massa de textura fresca, semifresca, semi-seca e seca. Algumas espécies de besouros coprófagos demonstram preferência por determinado tipo de textura da massa fecal. Durante os períodos chuvosos e frios há preferência pelas texturas frescas, e ao aumentar a temperatura e diminuir umidade há preferência por fezes mais desidratadas. Quando as temperaturas mínimas descem abaixo de $0{ }^{\circ} \mathrm{C}$, as fezes mais hidratadas se congelam com maior rapidez, e nestes casos a preferência é por fezes mais secas.

Ao se estudar a temperatura presente na massa fecal, na Dinamarca (Hammer ${ }^{2}$, citado por MACLINTOCK \& DEPNER, 1954), encontrou-se uma temperatura de cerca de $37,5^{\circ} \mathrm{C}$ no momento da deposição. A queda na temperatura da massa fecal varia de acordo com a hora e o dia. No calor $\left(21^{\circ} \mathrm{C}\right.$ a $\left.23^{\circ} \mathrm{C}\right)$ e dias

2 HAMMER, O. Biological and ecological investigations on flies associated with pasturing cattle and their excrement. vidensk. Medd. Dansk. Naturf. For Robenhavn. 105, p.141-393, 1942. 
ensolarados a temperatura nas fezes frescas, cai de 5 a $7{ }^{\circ} \mathrm{C}$ nas primeiras horas após a deposição pelo bovino. Sob condições de ar frio a temperatura cai mais rapidamente, portanto a massa fecal acompanha o ritmo da temperatura do dia e da noite. Após a insolação uma crosta é formada na massa fecal, e a temperatura dentro desta pode elevar-se lentamente. A temperatura na parte basal da massa fecal e na superfície do solo abaixo desta, são similares.

MATTHIESSEN \& PALMER (1988) estudando massas fecais de bovinos encontraram que a temperatura mínima das fezes combina com a do ar. A máxima temperatura das fezes é maior do que a do ar. Durante o dia a mínima temperatura do ar ocorreu às $04: 30 \mathrm{~h}$ e na massa fecal às 05:00h. A máxima temperatura do ar foi às 13:30h e da massa fecal às 14:00h e 14:30. Diariamente a temperatura máxima é afetada por fatores meteorológicos e estacionais.

Leituras de temperaturas foram realizadas por MOON (1983) em massas fecais, solo e ar, encontrando uma similaridade entre a primeira e segunda, respectivamente, enquanto que as temperaturas obtidas no período da tarde são maiores nas massas fecais do que no ar. A pesquisa teve por objetivo obter as temperaturas no campo para poder simular o tempo de desenvolvimento de M. autumnalis. DUDLEY (1979) ressaltou a importância do microclima onde se encontram as massas fecais, pois a temperatura tem influência na fauna de besouros coprófagos. 


\section{MATERIAL E MÉTODOS}

\subsection{Localização do experimento}

o experimento foi conduzido em áreas de pastagem e de Eucalyptus sp. com sub-bosque circundado por mata nativa, próximo ao Bairro Monte Alegre, localizado a $8 \mathrm{~km}$ da Universidade de São Paulo (ESALQ/USP), pertencente ao município de Piracicaba/SP.

\subsection{Besouros coprófagos}

\subsubsection{Coleta em dois ambientes}

Para se verificar as espécies de besouros coprófagos nativos ocorrentes em áreas de pastagem e de Eucalyptus sp. com sub-bosque circundado por mata nativa, bem como avaliar sua flutuação populacional e correlacionar com fatores climáticos, utilizou-se de 5 armadilhas "pitfall" iscadas com massa fecal de bovinos em cada local de coleta.

O uso de armadilhas "pitfall" tem sido empregada em estudos onde avalia-se a distribuição e comportamento populacional de besouros coprófagos (LOBO et al., 1988; RODRIGUES \& FLECHTMANN, 1993; RODRIGUES \& MARCHINI, 1996).

A armadilha "pitfall" consiste de um tripé de metal com cerca de $28 \mathrm{~cm}$ de altura, ao qual dependura-se um volume com cerca de $700 \mathrm{ml}$ de massa fecal fresca de bovino, envolta em tecido de voal. Imediatamente sob a massa, são colocados dois 
copos plásticos, um encaixado dentro do outro, de $350 \mathrm{ml}$ de volume, enterrados ao nível do solo, e preenchidos com água e detergente (LOBO et al., 1988) (Figura 1).

Passados 7 dias, os insetos coletados eram retirados e as armadilhas reinstaladas. Estas atuaram no período de 01/03 a $25 / 10 / 1996$.

A triagem e identificação dos insetos foi realizada no Departamento de Entomologia da Universidade de São Paulo (ESALQ/USP) em Piracicaba/SP.

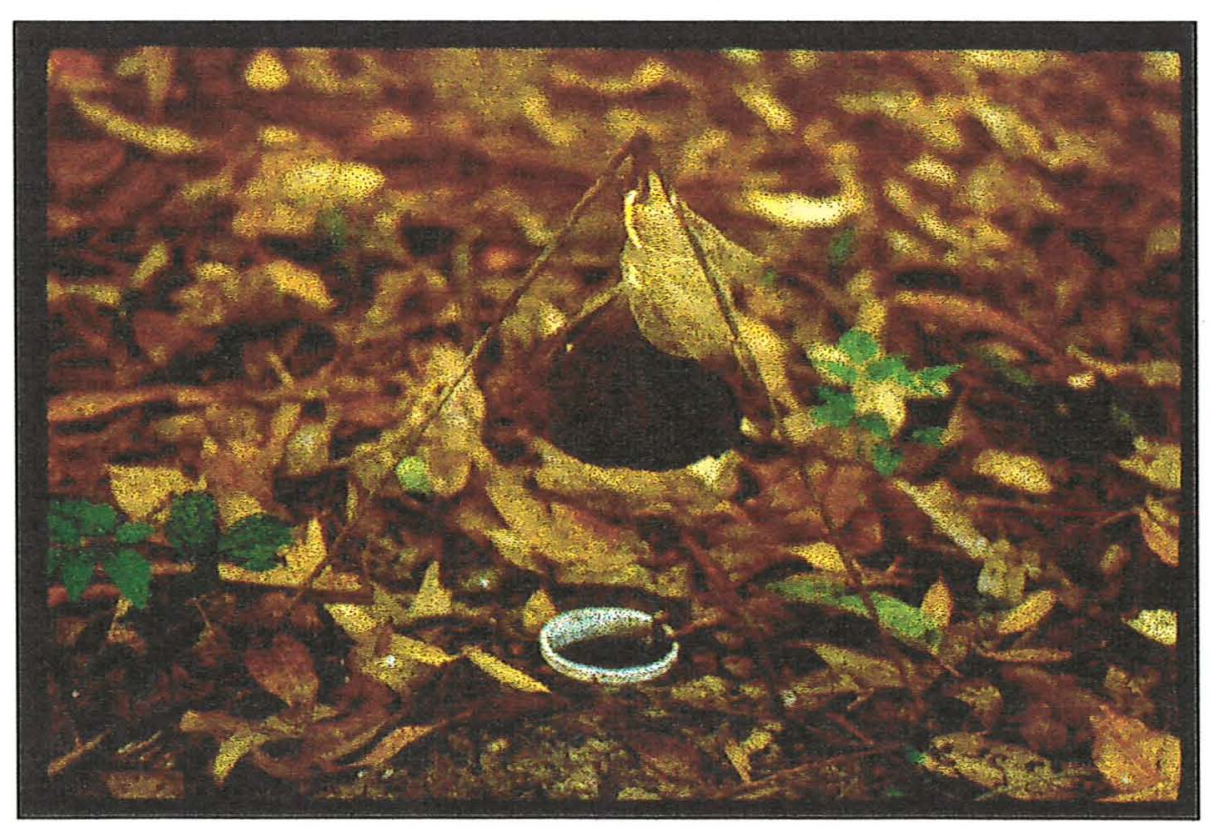

Figura 1. Armadilha "pitfall" com um volume de massa fecal funcionando como atrativo, e copo plástico com água e detergente para coleta de besouros coprófagos. 


\subsubsection{Análise faunística}

Após a coleta dos insetos nas distintas áreas experimentais, foi utilizado de índices faunísticos para auxiliar nas análises dos dados obtidos. Os índices empregados foram os de frequência, constância, abundância, diversidade e similaridade.

a) Indice de Frequência (F)

Foi determinado, para cada espécie coletada através do uso de armadilhas "pitfall" nas diferentes áreas estudadas. A fórmula utilizada como determinado por SILVEIRA NETO et al. (1976), foi:

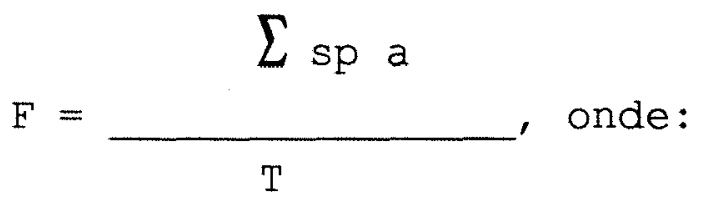

Esp a - total de individuos coletados para a espécie a $\mathrm{T}$ - total de indivíduos coletados (para todas as espécies)

Obtidos os valores de $F$ foi calculado o intervalo de confiança (IC) da média com 5\% de probabilidade, conforme FAZOLIN (1991), adotando-se a seguinte classificação:

- Muito frequente (MF) - número de indivíduos maior do que o limite superior do IC a $5 \%$.

- Frequente (F) - número de indivíduos situados dentro do IC a 5 응.

- Pouco frequente (PF) - número de indivíduos menor do que o limite inferior do IC a 5\%. 
b) Constância

O índice de constância foi calculado pela fórmula que segue (SILVEIRA NETO et al., 1976):

$P \times 100$

C $\left(\frac{\circ}{0}\right)=$ onde

$\mathrm{N}$

P - número de coletas com a espécie estudada

$\mathrm{N}$ - número total de coletas efetuadas

Obtidos os valores de $C$, a classificação das categorias foi feita através do cálculo do intervalo de confiança, segundo WILCKEN (1991). De acordo com os valores obtidos a 5\% de probabilidade as espécies foram agrupadas nas seguintes categorias:

- espécies constantes (w): presentes em mais de 50\% das coletas;

- espécies acessórias (y): presentes entre 25\% e 50\% das coletas;

- espécies acidentais ( $z$ ): presentes em menos de 25\% das coletas.

c) Índice de Abundância

- indice de abundância foi calculado para cada espécie capturada, sendo empregado uma medida de dispersão, através do cálculo do desvio padrão, erro padrão da média e intervalo de confiança (IC), utilizando-se o teste "t" a 5\% e 1\% de probabilidade (SILVEIRA NETO et al., 1976). Foram estabelecidas as seguintes classes de abundância para as espécies: 
- Rara ( $r$ ): número de indivíduos menor do que o limite inferior do IC a $1 \%$ de probabilidade;

- Dispersa (d): número de indivíduos situado entre os limites inferiores do IC a $5 \%$ e $1 \%$ de probabilidade;

- Comum (C) : número de indivíduos situado dentro dos limites do IC a 5\% de probabilidade;

- Abundante (a): número de indivíduos situados entre os limites superiores do IC a $5 \%$ e $1 \%$ de probabilidade;

- Muito abundante (m): número de indivíduos superior ao limite superior do IC a $1 \%$ de probabilidade;

Devido ao número de Dichotomius anaglypticus, Aphodius pseudolividus e Ataenius sp.2 coletados na área de pastagem e de $A$. pseudolividus na área de Eucalyptus sp. com sub-bosque, excederem muito aos demais, eles foram classificados como super abundantes (SA), não sendo incluídos para o cálculo das demais categorias deste índice.

d) Indice de diversidade ( $\alpha)$

O cálculo da diversidade foi realizado para cada espécie, nas distintas áreas. A fórmula usada é a de Margalef ${ }^{3}$ citado por SILVEIRA NETO et al. (1976):

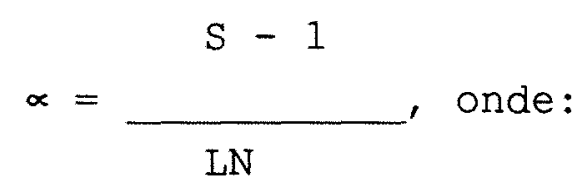

S - número de espécies de cada local

LN - logaritmo neperiano do número de indivíduos do local

3 MARGALEF, R. Diversidad de espécies en las comunidades naturales. Publicaciones Del Instituto de Biologia Aplicada de Barcelona, Barcelona, 6:59-72, 1951. 
e) Quociente de similaridade

Com a finalidade de verificar a semelhança entre as duas comunidades estudadas, foi calculado $\circ$ quociente de similaridade de acordo com a fórmula estabelecida por Sorensen 4 , citado por SILVEIRA NETO et al. (1976):

$$
Q S=\frac{2 J}{a+b}
$$

Onde:

$$
\begin{aligned}
& \mathrm{J}=\text { número de espécies encontradas em ambos habitats } \\
& \mathrm{a}=\text { número de espécies no habitat } \mathrm{A} \\
& \mathrm{b}=\text { número de espécies no habitat } \mathrm{B}
\end{aligned}
$$

f) Porcentagem de Similaridade

objetivando avaliar a semelhança entre locais utilizando-se apenas espécies comuns a eles, aplicou-se o índice, baseando-se na somatória dos menores valores de porcentagem do total de individuos comuns aos dois locais, proposto por SOUTHWOOD (1971), sendo:

$$
\div S=\sum \min \left(\frac{\circ}{a}+\frac{\circ}{b}+\ldots+\frac{8}{0} n\right)
$$

Onde:

$\circ \mathrm{S}=\frac{\circ}{\circ}$ de similaridade

4 SORENSEN, T. A method of stablishing of equal amplitude in plant sociology based on similarity of species contend and its aplication to analyses of the vegetation on danish commons. Biol. Skr., Estocolmo, 5:1-34, 1948. 
$\mathrm{a}=$ menor porcentagem do taxon a observado no confronto dos dois locais

$\mathrm{b}=$ menor porcentagem do taxon $\mathrm{b}$ observado no confronto dos dois locais

\subsection{Estudo das temperaturas na massa fecal e ambiente}

\subsubsection{Determinação das temperaturas}

Nos dias de coleta dos besouros coprófagos através do uso de armadilhas "pitfall", realizou-se leituras de temperaturas com auxílio de termopar modelo TDB 40C12, em massas fecais de bovinos e no ambiente.

As massas fecais (MF), foram separadas em 4 distintas idades como proposto por FLECHTMANN et al. (1995b), dividindoas em MF1 (recém-escretada, sem crosta superficial, com teor médio de $82,59 \%$ de umidade), MF2 (apresentando fina crosta superficial e umidade média de 79,63\%), MF3 (com crosta significativamente mais rigida, e 64,13\% de umidade) e MF4 (ressecada, apresentando umidade média igual ou inferior a $17,04 \%)$.

Após a separação das massas fecais realizaram-se leituras de temperaturas em três regiões: na camada externa, no centro e na interface entre o solo e a massa. Nas áreas de pastagem e Eucalyptus sp. com sub-bosque, também se tomaram leituras de temperatura na camada superficial do solo, e a um metro de altura (Figura 2).

Para verificar as temperaturas presentes em massas fecais durante o dia, realizaram-se leituras às 8:00 e 14:00 h no dia 05/04/1996 e às 8:00, 12:00 e 16:00 h no dia 06/06/1996, em massas fecais de diferentes idades, a um metro de altura e ao nível do solo na área de pastagem. 

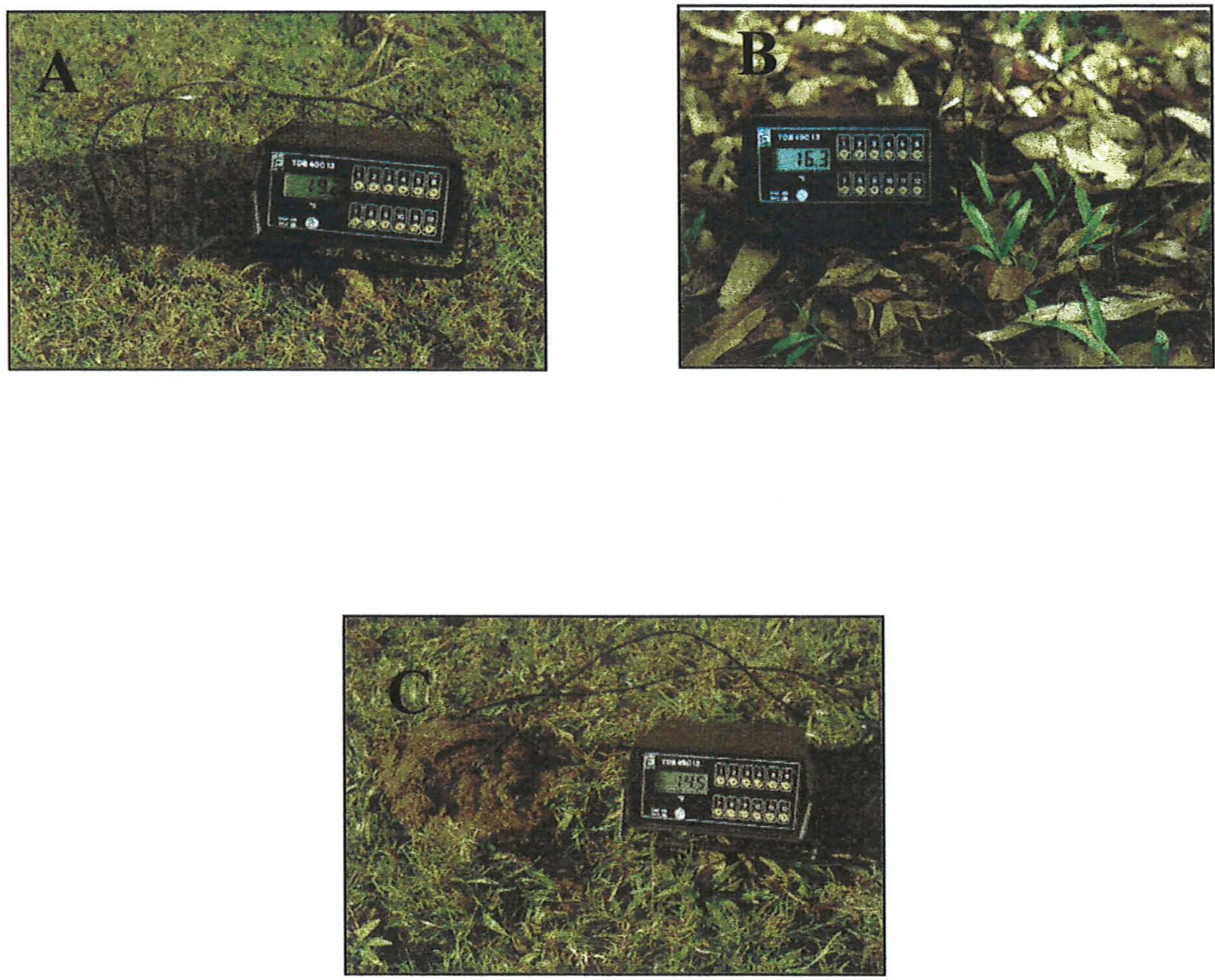

Figura 2. Termopar modelo TDB 40C12, utilizado para leituras de temperaturas na superfície do solo em áreas de pastagem (A) e Eucalyptus sp. com sub-bosque (B), e massa fecal de bovinos (C). 
- período de março a outubro foi utilizado para leituras de temperatura das massas fecais nas distintas áreas estudadas, pois segundo ALVES (1977) elas podem permanecer por 8 meses no campo, se depositada na estação chuvosa do ano.

A partir de 09/08/1996 passou-se a tomar leituras de temperaturas também a $5 \mathrm{~cm}$ de profundidade no solo da área de pastagem, local onde as larvas de mosca-dos-chifres costumam pupar.

\subsubsection{Análise estatística}

Foi efetuada a análise da variância empregando o teste de Tukey $(\mathrm{P}<0,05)$ para comparação de médias das variáveis: temperatura ambiente $e$ das massas fecais. A temperatura ambiente foi considerada a média entre o nível do solo e a um metro de altura e a temperatura das massas fecais a média das temperaturas nas regiões da superfície, interior e interface.

As temperaturas médias descritas acima, foram também utilizadas na análise de correlação e regressão entre temperatura ambiente e idade de massa fecal.

As temperaturas obtidas nas regiões das massas fecais, ao nível do solo e a um metro de altura, foram submetidas a análise de variância, e as médias comparadas pelo teste de Tukey, ao nível de 5\% de probabilidade.

\subsection{Determinação das exigências térmicas de $H$. irritans}

o cálculo do limiar térmico inferior (Tb) e da constante térmica $(K)$ foi realizado utilizando-se o método da hipérbole (HADDAD \& PARRA, 1984), baseando-se na duração do 
período de ovo a adulto nas temperaturas de $18,25,30$ e $33^{\circ} \mathrm{C}$, cuja duração é de $26,14,9,9$ e 9,0 dias, respectivamente (MACLINTOCK \& DEPNER, 1954; HONER et al., 1990).

\subsection{Dados meteorológicos}

Através da estação Hidrometeorológica da Escola Superior de Agricultura "Luiz de Queiroz" (ESALQ/USP), localizada no município de Piracicaba, distante a poucos quilômetros do local da condução do experimento, foram obtidos dados de temperatura, umidade relativa do ar e precipitação pluvial, durante o período de condução do experimento.

os dados de temperatura abrangeram:

- TMAX: temperatura máxima $\left({ }^{\circ} \mathrm{C}\right)$ da semana da instalação das armadilhas;

- TMED: temperatura média $\left({ }^{\circ} \mathrm{C}\right)$ da semana da instalação das armadilhas;

- TMIN: temperatura mínima $\left({ }^{\circ} \mathrm{C}\right)$ da semana da instalação das armadilhas;

Para umidade relativa do ar, foi usado:

- UR: umidade relativa (\%) da semana da instalação das armadilhas;

Para a precipitação pluvial, foi usado:

- PPT: precipitação pluvial acumulada na semana de instalação das armadilhas; 


\section{RESULTADOS E DISCUSSÃo}

\subsection{Espécies coletadas}

Durante o período de instalação das armadilhas, coletou-se um total de 13 espécies de besouros coprófagos, distribuídos em 2 sub-famílias e 4 tribos:

A. Sub-família Scarabaeinae

Nessa sub-família os insetos coletados pertencem a duas tribos.

a) Tribo Coprini

As espécies capturadas foram identificadas como:

Dichotomius anaglypticus

Dichotomius mormon

Gromphas lacordairei

Eurysternus caribaeus

Trichillum externepunctatum

Uroxys sp.

b) Tribo Scarabaeini

A espécie capturada foi identificada como:

Canthon virens 
B. Sub-família Aphodiinae

As espécies coletadas nessa sub-família estão distribuidas em duas tribos.

c) Tribo Aphodiini

Aphodius nigrita

Aphodius pseudolividus

d) Tribo Eupariini
Ataenius picinus
Ataenius sculptor
Ataenius spl.
Ataenius sp2.

Utilizando-se da classificação proposta por WATERHOUSE (1974), verificou-se que as espécies coletadas enquadram-se nos grupos dos besouros com hábito paracoprídeo, endocoprídeo e telecoprídeo.

As espécies com hábito paracoprídeo pertencem aos gêneros Dichotomius e Gromphas, as de hábito endocoprídeo pertencem aos gêneros Ataenius, Aphodius, Trichillum, Eurysternus e Uroxys, e com hábito telecoprídeo é representado pelo gênero Canthon.

As espécies de hábito endocoprídeo, paracoprídeo e telecoprídeo compreenderam respectivamente $69,23,23,08$ e 7,69\% do total de individuos coletados.

\subsubsection{Espécies na área de pastagem}

Na área de pastagem coletou-se um total de 8 espécies 
de besouros coprófagos (Tabela 1). Dessas apenas duas apresentaram hábito paracoprídeo, enquanto que as demais hábito endocoprídeo.

Tabela 1. Total de Scarabaeidae coprófagos coletados em área de pastagem, durante o período de 01/03 a 25/10/1996. Piracicaba/SP.

\begin{tabular}{lcl}
\hline Espécies & Quantidade & Hábito \\
\hline Dichotomius anaglypticus & 80 & Paracoprídeo \\
Gromphas lacordairei & 1 & Paracoprídeo \\
Ataenius picinus & 4 & Endocoprídeo \\
Ataenius sp.1 & 1 & Endocoprídeo \\
Ataenius sp.2 & 84 & Endocoprídeo \\
Aphodius pseudolividus & 113 & Encocoprídeo \\
Aphodius nigrita & 5 & Endocoprídeo \\
Trichillum externepunctatum & 2 & Endocoprídeo \\
\hline Total de espécies & 8 & \\
Total de individuos & 290 & \\
\hline
\end{tabular}

Devido ao comportamento de incorporação os paracoprídeos podem remover completamente uma massa fecal da superfície do solo, retirando assim todo o ambiente de desenvolvimento de larvas de moscas e helmintos.

Dentre os paracoprídeos a espécie coletada em maior quantidade foi $D$. anaglypticus, que representou 27,59\% do total de insetos capturados. Ocorreu durante o período de março até - início do mês de maio, período esse onde o clima é quente e úmido. A partir do mês de maio a temperatura e precipitação pluvial diminuem e essa espécie não é mais coletada no campo (Figuras 3 e 4 ). 

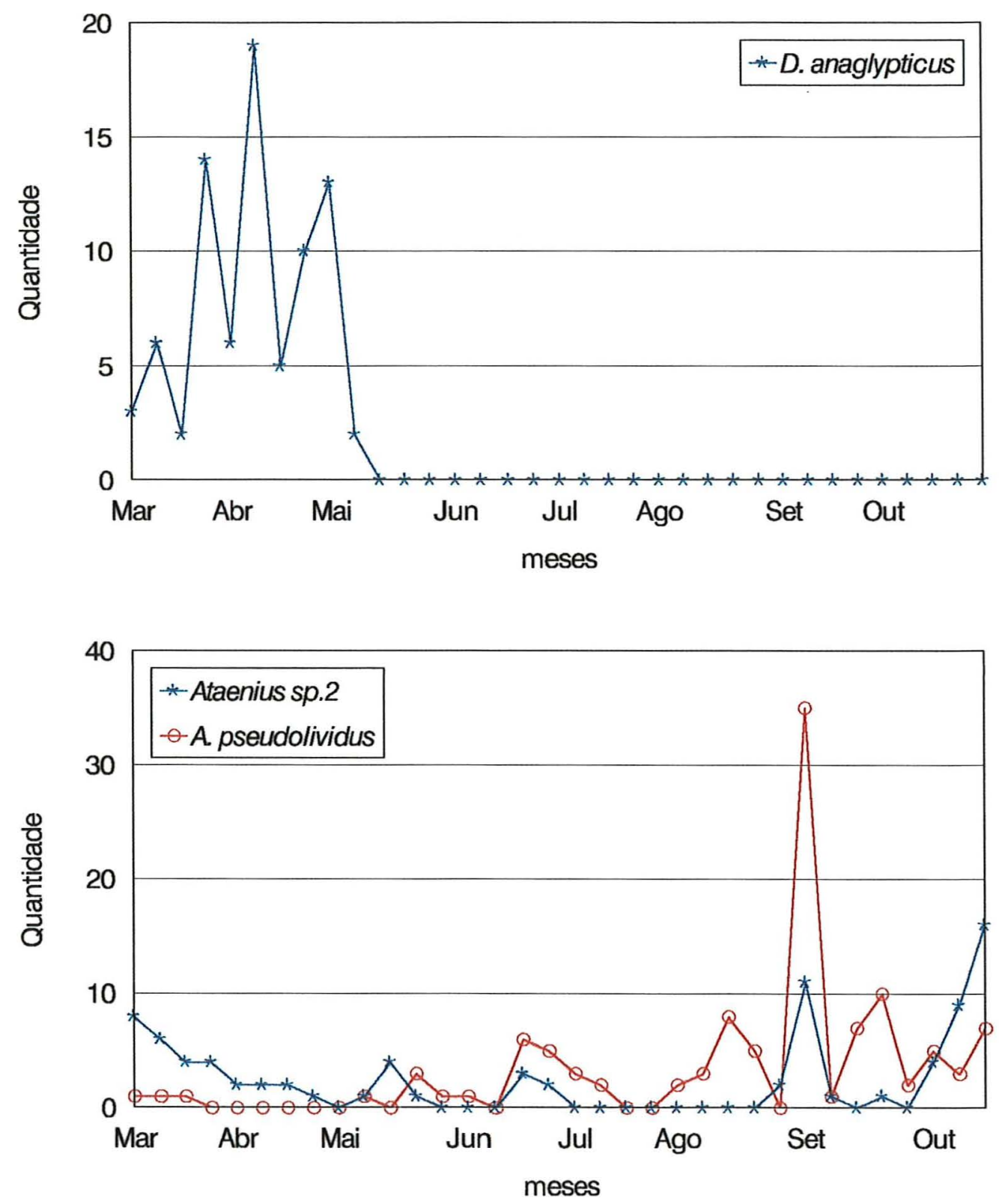

Figura 3. Capturas mensais de Dichotomius anaglypticus, Aphodius pseudolividus e Ataenius sp.2, em armadilha "pitfall", durante o período de 01/03 a 25/10/1996. Piracicaba/SP. 

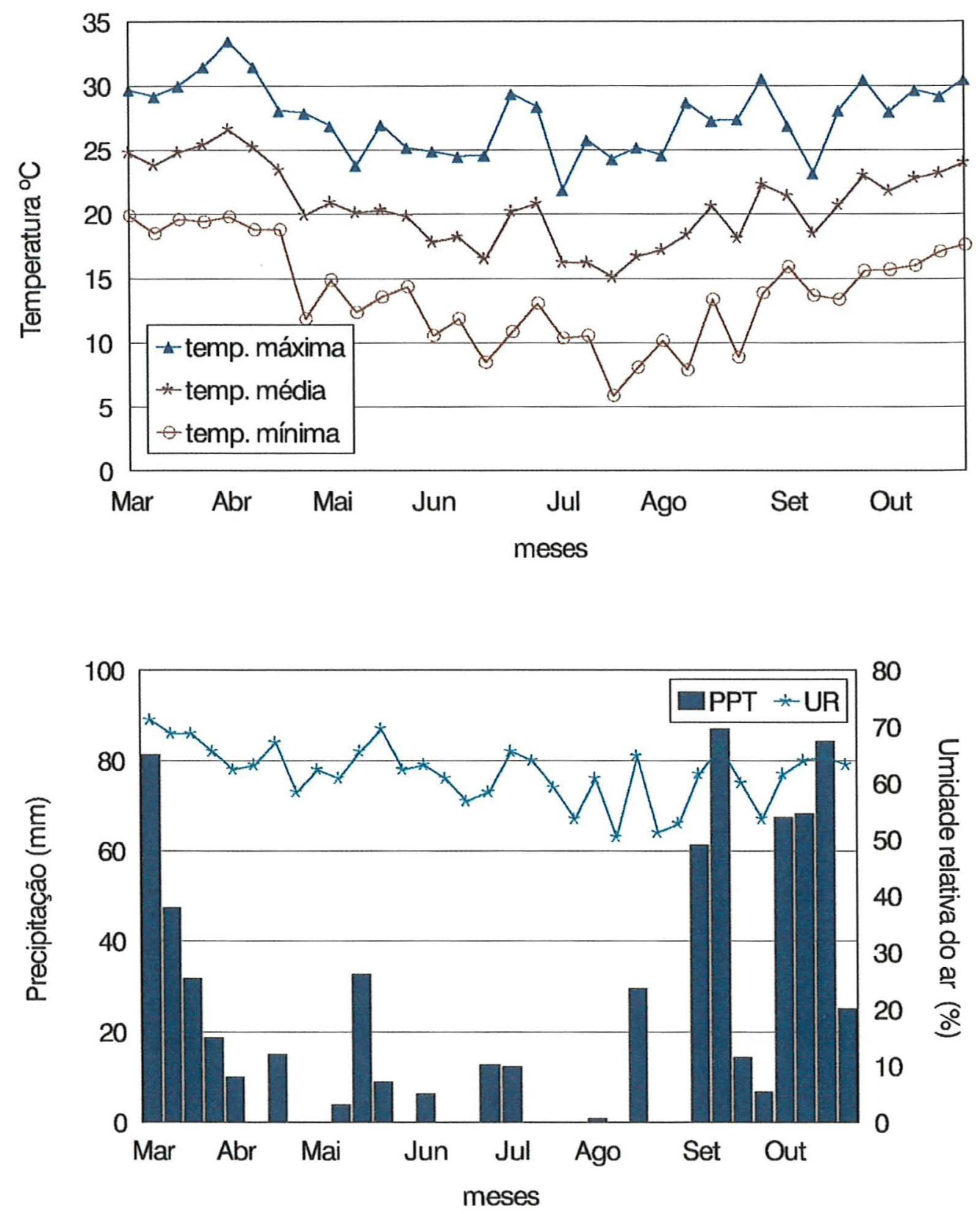

Figura 4. Dados mensais de temperaturas máxima, média e mínima $\left({ }^{0} \mathrm{C}\right)$, precipitação pluvial (PPT) e umidade relativa do ar (UR) durante o período de 01/03 a 25/10/1996. Piracicaba/SP. 
As espécies dos gêneros Aphodius e Ataenius coletadas não removem massas fecais, vivem apenas dentro destas. Após a localização e instalação nas fezes no campo, elas caminham e constroem pequenos canais, os quais permitem a entrada e circulação de ar, levando a massa a um ressecamento mais rápido do que se não tivesse sido colonizada.

As espécies Ataenius sp.2 e A. pseudolividus foram coletadas em grande quantidade e representaram respectivamente 28,97 e 38,97\% do total de insetos coletados. Na área estudada ambas foram coletadas praticamente durante todo o período de instalação das armadilhas, mesmo durante o período de maio a agosto quando as temperaturas e umidade são baixas (Figuras 3 e 4).

Aphodius nigrita, Ataenius picinus e Trichillum externepunctatum foram coletados em pequena quantidade correspondendo respectivamente a 1,72, 1,38 e 0,69\% do total de insetos capturados.

\subsubsection{Espécies na área de Eucalyptus sp. com sub-bosque}

Um total de 9 espécies de besouros coprófagos ocorreram nesta área, e destes 6 apresentaram hábito endocoprídeo, 2 hábito paracoprídeo e 1 hábito telecoprídeo (Tabela 2).

As espécies D. anaglypticus, D. mormon e Eurysternus caribaeus, A. pseudolividus, Ataenius sp.2, Ataenius sculptor, Ataenius picinus, Canthon virens e Uroxys sp., representaram respectivamente 5,$45 ; 0,91 ; 1,82 ; 76,36 ; 9,09 ; 0,91 ; 3,64 ; 0,91$ e $0,91 \%$ das espécies coletadas.

Excetuando-se A. pseudolividus todas as espécies foram coletadas em pequena quantidade, 0 que pode estar associado a pouca oferta e/ou tipo de alimento nessa área. 
Tabela 2. Total de Scarabaeidae coprófagos coletados em área de Eucalyptus sp. com sub-bosque, durante o período de 01/03 a 25/10/1996. Piracicaba/SP.

\begin{tabular}{lcl}
\hline Espécies & Quantidade & Hábito \\
& & \\
\hline Dichotomius anaglypticus & 6 & Paracoprídeo \\
Dichotomius mormom & 1 & Paracoprídeo \\
Uroxys sp. & 1 & Endocoprídeo \\
Eurysternus caribaeus & 2 & Endocoprídeo \\
Ataenius sp.2 & 10 & Endocoprídeo \\
Ataenius picinus & 4 & Endocoprídeo \\
Ataenius sculptor & 1 & Endocoprídeo \\
Aphodius pseudolividus & 84 & Endocoprídeo \\
Canthon virens & 1 & Telecoprideo \\
\hline Total de espécies & & \\
Total de individuos & 110 & \\
\hline
\end{tabular}

\subsubsection{Preferência por ambientes}

Das espécies de besouros coprófagos coletadas algumas ocorreram nos dois ambientes, enquanto que outras em um apenas. Nos dois ambientes estudados houve maior ocorrência de espécies coprófagas com hábito endocoprídeo.

Em termos quantitativos na área de pastagem coletouse cerca de 290 indivíduos, enquanto que em Eucalyptus sp. com sub-bosque, obteve 110 indivíduos, entretanto maior número de espécies foram coletadas na área de Eucalyptus sp. (9 espécies) do que na área de pastagem ( 8 espécies).

A espécie D. anaglypticus foi coletada nos dois 
ambientes, entretanto em maior quantidade na área de pastagem. Comportamento semelhante foi observado para Ataenius sp.2 e Aphodius pseudolividus. Ataenius picinus também ocorreu nos dois locais mas em pequena quantidade.

Dichotomius mormon, E. caribaeus, A. sculptor, Uroxys sp. e Canthon virens foram coletados apenas em área de Eucalyptus sp. com sub-bosque, enquanto que G. lacordairei, A. nigrita, Ataenius sp.1 e Trichillum externepunctatum apenas em área de pastagem.

\subsection{Caracterização das comunidades}

\subsubsection{Indíces de frequência, abundância, constância e diversidade das diferentes áreas}

\subsubsection{1. Área de pastagem}

Uma distribuição porcentual da análise faunística das espécies capturadas na área de pastagem está representada na Tabela 3.

Analisando-se o índice de frequência, observou-se que cerca de $50 \%$ das espécies enquadram-se na categoria muito frequentes e 50\% frequentes. As espécies $D$. anaglypticus, $A$. pseudolividus, Aphodius nigrita e Ataenius sp.2 foram as espécies classificadas como muito frequentes, enquanto que as outras nas demais categorias.

Para o indice de abundância, cerca de $37,50 \%$ das espécies foram classificadas como super abundantes, 12,50\% como abundantes e 50\% como comuns. As espécies $D$. anaglypticus, $A$. pseudolividus e Ataenius sp.2 foram as classificadas como super abundantes, A. nigrita foi classificada como abundante e as demais comuns.

O índice de constância apresentou $37,50 \%$ das espécies como 
constantes e $62,50 \%$ como acessórias. As espécies constantes foram D. anaglypticus, A. pseudolividus e Ataenius sp.2 e as demais acessórias.

Tabela 3. Distribuição porcentual das espécies capturadas com armadilha "pitfall" em área de pastagem, durante 0 período de 01/03 a 25/10/1996. Piracicaba/SP.

\begin{tabular}{|c|c|c|c|}
\hline Indices faunísticos & Classificação & Total & $\%$ \\
\hline & Muito frequente (MF) & 4 & 50,00 \\
\hline \multirow[t]{5}{*}{ Frequência } & Frequente (F) & 4 & 50,00 \\
\hline & Pouco frequente (PF) & 0 & 0 \\
\hline & Super abundante (SA) & 3 & 37,50 \\
\hline & Muito abundante (MA) & 0 & 0 \\
\hline & Abundante (A) & 1 & 12,50 \\
\hline \multirow[t]{4}{*}{ Abundância } & Comum (C) & 4 & 50,00 \\
\hline & Dispersa (D) & 0 & 0 \\
\hline & Rara (R) & 0 & 0 \\
\hline & Constante (W) & 3 & 37,50 \\
\hline \multirow[t]{2}{*}{ Constância } & Acessória (Y) & 5 & 62,50 \\
\hline & Acidental (Z) & 0 & 0 \\
\hline Total de espécies & & 8 & \\
\hline Total de individuos & & 290 & \\
\hline
\end{tabular}




\subsubsection{2. Área de Eucalyptus sp. com sub-bosque}

Uma distribuição porcentual da análise faunística das espécies capturadas na área de Eucalyptus sp. está representada na Tabela 4.

Tabela 4. Distribuição porcentual das espécies capturadas com armadilha "pitfall" em área de Eucalyptus sp. com sub-bosque, durante o período de 01/03 a 25/10/1996. Piracicaba/SP.

Índices faunísticos Classificação

Total

$\%$

\begin{tabular}{|c|c|c|c|}
\hline \multirow{3}{*}{ Frequência } & \multirow{2}{*}{$\begin{array}{l}\text { Muito frequente } \\
\text { Frequente (F) }\end{array}$} & \multirow{2}{*}{$\begin{array}{l}3 \\
6\end{array}$} & \multirow{2}{*}{$\begin{array}{l}33,33 \\
66,67\end{array}$} \\
\hline & & & \\
\hline & Pouco frequente (PF) & 0 & 0 \\
\hline \multirow{6}{*}{ Abundância } & Super abundante (SA) & 1 & 11,11 \\
\hline & Muito abundante (MA) & 1 & 11,11 \\
\hline & Abundante (A) & 1 & 11,11 \\
\hline & Comum (C) & 6 & 66,67 \\
\hline & Dispersa (D) & 0 & 0 \\
\hline & Rara (R) & 0 & 0 \\
\hline \multirow{3}{*}{ Constância } & Constante (W) & 3 & 33,33 \\
\hline & Acessória (Y) & 6 & 66,67 \\
\hline & Acidental (Z) & 0 & 0 \\
\hline \multicolumn{2}{|c|}{ Total de espécies } & 9 & \\
\hline \multicolumn{2}{|c|}{ Total de indíviduos } & 110 & \\
\hline
\end{tabular}


Encontrou-se para 0 índice de frequência, 33,33\% das espécies classificadas como muito frequentes, representadas por D. anaglypticus, A. pseudolividus e Ataenius sp.2, enquanto que $66,67 \%$ das espécies foram classificadas como frequentes.

Para $O$ índice de abundância, 11,11\% das espécies foram classificadas como super abundantes, representada por $A$. pseudolividus, $11,11 \%$ muito abundantes, representada por Ataenius sp.2, $11,11 \%$ abundantes, representada por $D$. anaglypticus e $66,67 \%$ comuns.

Para 0 indice de constância, 33,33\% das espécies foram constantes, representadas por $D$. anaglypticus, $A$. pseudolividus e Ataenius sp.2 e 66,67\% acessórias.

\subsubsection{Indíce de diversidade}

Na Tabela 5 encontram-se os valores dos índices de diversidade $(\alpha)$, bem como o número de espécies (S) e total de individuos $(\mathrm{N})$ de besouros coprófagos coletados nos diferentes locais.

Tabela 5. Número de espécies (S), número de indivíduos (N) e indice de diversidade $(\alpha)$, referentes aos diferentes locais de coletas de besouros coprófagos, durante o período de 01/03 a 25/10/1996. Piracicaba/SP.

\begin{tabular}{llll}
\hline LOCAL & S & N & $\propto$ \\
\hline Pastagem & 8 & 290 & 1,23 \\
Eucalyptus sp. & 9 & 110 & 1,70 \\
\hline
\end{tabular}

Houve pouca diferença para a diversidade dentre os 
locais onde coletaram-se besouros coprófagos, com uma pequena superioridade para a área de Eucalyptus sp. com sub-bosque. RODRIGUES \& FLECHTMANN (1993) estudando a fauna coprófaga em área de mata, transição e pasto encontraram maior quantidade de espécies coprófagas nas duas primeiras áreas, e indice de diversidade (Margalef) de 4,96, 4,85 e 3,39 para as respectivas áreas, na região de Selvíria/MS.

\subsubsection{Indice de similaridade}

Tabela 6. Número de espécies coletadas, espécies comuns, quociente de similaridade (QS) e porcentagem de similaridade (S) entre as áreas estudadas, durante o período de 01/03 a 25/10/1996. Piracicaba/SP.

\begin{tabular}{|c|c|c|c|c|c|}
\hline & Pasto & Eucalyptus sp. & Comuns & QS & S \\
\hline TOTAIS & 8 & 9 & 4 & 0,47 & 54,89 \\
\hline
\end{tabular}

Os índices utilizados apresentaram valores próximos de similaridade. A similaridade encontrada pode ser considerada alta entre as espécies coletadas nos locais. Provavelmente a pequena quantidade de espécies coletadas deve ter proporcionado o alto índice.

\subsection{Temperaturas nas diferentes áreas}

Durante os meses de avaliações das temperaturas (Tabela 7) (Figura 5) nas áreas estudadas, foi encontrado ao 
nível do solo temperatura sempre maior do que a um metro de altura.

$\mathrm{Na}$ área de pastagem pode-se observar médias de temperaturas mais elevadas, e maiores oscilações térmicas quando comparada a área de Eucalyptus sp. com sub-bosque, havendo diferenças estatísticas entre essas.

A vegetação presente na área de Eucalyptus sp. com sub-bosque, proporciona maior sombreamento na camada superficial do solo e a um metro de altura no ambiente, provocando assim, menores temperaturas e menores oscilações térmicas.

Um outro fator influente nas maiores oscilações térmicas no pasto é o vento, pois este é mais constante e intenso no pasto do que na área de Eucalyptus sp. com subbosque.

Os dados aqui encontrados coincidem com a afirmativa de HALFFTER et al. (1992), que relata maiores temperaturas médias do ar e solo em áreas de pastagens, havendo a formação de severos micro-macroclimas.

Nos ambientes estudados houve a formação de diferentes microclimas, e para os besouros coprófagos as temperaturas encontradas tornam-se muito importantes, podendose explicar parcialmente por que algumas espécies ocorrem apenas no pasto ou em área de Eucalyptus sp. com sub-bosque.

Como discutido no item 4.1.3. algumas espécies ocorreram em apenas um determinado ambiente. Para as espécies que ocorreram apenas na área de Eucalyptus sp. com sub-bosque, provavelmente não apresentam condições de explorar a área de pastagem.

Talvez a ocorrência das espécies coprófagas na área de pastagem, não dependa da quantidade de alimento, que é abundante nesta e sim do tipo de alimento e também das condições microclimáticas reinantes no local. 

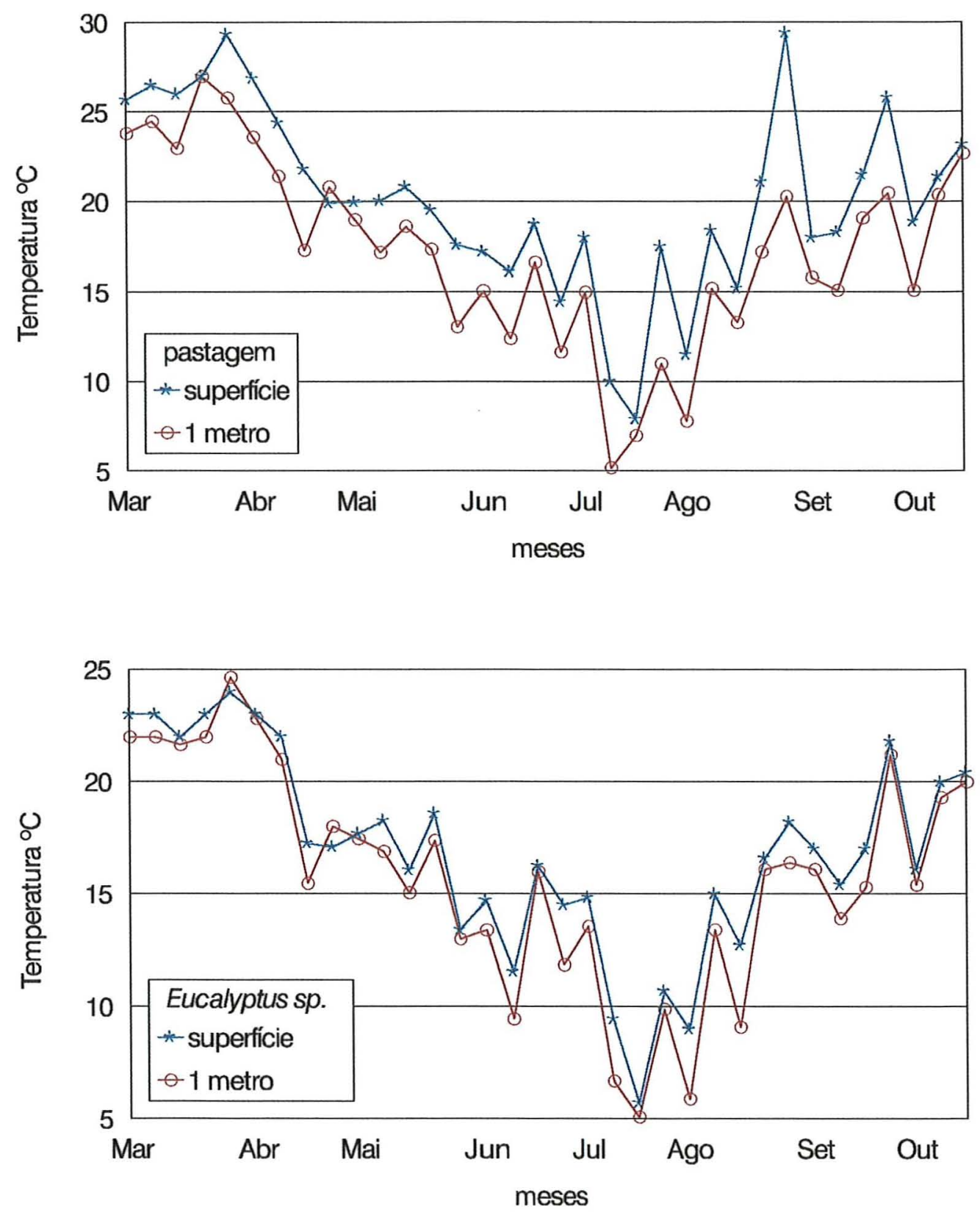

Figura 5. Valores mensais de temperaturas na superfície do solo e a um metro de altura nas áreas de pastagem e Eucalyptus sp. com sub-bosque, durante o período de 01/03 a 25/10/1996. Piracicaba/SP. 
Tabela 7. Valores médios de temperaturas obtidos para áreas de pastagem e Eucalyptus $\mathrm{sp}$. com sub-bosque na superfície do solo e a um metro de altura nos ambientes, durante o período de 01/03 a 25/10/1996. Piracicaba/SP.

\begin{tabular}{lllll}
\hline & \multicolumn{2}{c}{ Pasto } & Eucalyptus sp. \\
\cline { 2 - 5 } & solo & $1 \mathrm{~m}$ & solo & $1 \mathrm{~m}$ \\
\hline & & & & \\
\hline & $20,24 \mathrm{a}^{1}$ & $17,33 \mathrm{~b}$ & $16,95 \mathrm{~b}$ & $15,86 \mathrm{c}$ \\
\hline
\end{tabular}

1 Médias seguidas pela mesma letra não diferem entre si ao nível de $5 \%$ de probabilidade pelo teste de Tukey.

Algumas espécies de besouros coprófagos ocorreram nas duas áreas, e podem assim estarem se adaptando ao microclima presente na área de pastagem e as fezes de bovinos disponíveis. Com auxilio das análises faunísticas estudadas nos itens 4.2.1.1, e 4.2.1.2., e com os dados de temperaturas encontrados nos dois ambientes, mostram que D. anaglypticus, A. pseudolividus e Ataenius sp.2, parecem suportar bem as condições da área de pastagem, por ocorrer em grande quantidade nesse ambiente.

\subsection{Importância das espécies para a pastagem}

As espécies ocorrentes em áreas de floresta, são os 
primeiros decompositores das massas fecais, sendo essa uma das importâncias do grupo de insetos para o ambiente (KLEIN, 1989) . Como a área de pastagem possui bovinos produzindo continuamente massas fecais, o sucesso na limpeza das massas depositadas depende exclusivamente da ação das espécies coprófagas que aí ocorrem.

Das espécies coletadas na área de pastagem, $D$. anaglypticus é a espécie de maior importância na incorporação de massas fecais de bovinos (ALVES, 1977), sendo classificada como besouro de tamanho grande (FLECHTMANN et al., 1995a).

Outra importante espécie para área de pastagem é $G$. lacordairei, que apresenta tamanho médio e é encontrado em grande quantidade em locais como Jaraguá do Sul/SC (FLECHTMANN et al., 1995a; FLECHTMANN \& RODRIGUES, 1995).

Nos meses de março a maio observou-se maior remoção de massas fecais no campo e como $D$. anaglypticus foi a espécie coletada em maior quantidade, é tida como principal responsável por tal serviço.

Durante os meses de maio a setembro pouca remoção de massa fecal foi observado, o que explica a não coleta de insetos de tamanho médio ou grande nas armadilhas "pitfall" durante esse período.

Com a remoção de massas fecais também se diminuiu o ambiente de desenvolvimento de larvas de moscas e de helmintos gastrointestinais. Como ocorreu maior atividade de incorporação de fezes de março a maio, nesse período houve menor porcentagem de fezes no campo para servirem de alimento e/ou abrigo a esses agentes parasitários.

Essa avaliação das espécies coprófagas na região, tem importância relevante por ter sido constatado em outubro a ocorrrência de $H$. irritans na propriedade, onde a pesquisa foi conduzida. 


\subsection{Temperaturas em massas fecais e na pastagem}

\subsubsection{Comportamento ao longo dos meses}

Não houve diferença entre as temperaturas médias das massas fecais e da pastagem e sim entre massas fecais de idades dois e quatro (Tabela 8).

Tabela 8. Valores médios de temperaturas em massas fecais de quatro idades diferentes (MF1, MF2, MF3 e MF4) e em ambiente de pastagem, durante o período de 01/03 a 25/10/1996. Piracicaba/SP.

\begin{tabular}{lc}
\hline Local & Temperatura ${ }^{0} \mathrm{C}$ \\
\hline MF4 & $19,03 \mathrm{a}^{1}$ \\
pastagem & $18,73 \mathrm{ab}$ \\
MF1 & $18,12 \mathrm{ab}$ \\
MF3 & $18,11 \mathrm{ab}$ \\
MF2 & $17,95 \mathrm{~b}$ \\
\hline
\end{tabular}

1 Médias seguidas pela mesma letra não diferem entre si ao nível de $5 \%$ de probabilidade pelo teste de Tukey.

Com relação a idade e umidade das massas fecais, observou-se que quanto mais nova e consequentemente maior a umidade, menor foi a temperatura presente.

As temperaturas médias presentes nas três regiões (superficie, interior e interface), apresentaram-se diferentes entre si. Na região da superfície ocorreu as maiores temperaturas nas massas fecais independente da idade, enquanto que no interior e interface ocorreram valores menores (Tabela 
9). Os dados encontrados coincidem com o observado por LANDIN (1961) que obteve maiores temperaturas na camada superficial de massas fecais de bovinos.

Para massas fecais de idades 1,2 e 3 as temperaturas médias no interior foram menores do que as da superfície e da interface com o solo, enquanto que no interior de idade 4 foi maior ao encontrado na interface com o solo.

As temperaturas da massa fecal de idade 4, foram sempre maiores do que as encontradas nas demais idades, com exceção da temperatura na interface que foi um pouco inferior a encontrada na idade um.

HOLTER (1988) ao dividir massas fecais em diferentes seções encontraram que Aphodius spp. preferiram certos locais, enquanto que espécies do mesmo gênero eram generalistas. A. haemorrhoidalis e $A$. uctericus foram encontrados em dias de sol, na região logo abaixo da superfície das fezes, pois ali ocorriam as temperaturas mais elevadas.

Os dados encontrados no presente trabalho sugerem a existência de um microclima em cada idade de massa fecal. Dentro da massa ocorreram áreas com diferentes temperaturas que podem ser preferidas por determinadas espécies de besouros coprófagos, como demonstrado por HOLTER (1988).

O fato de algumas espécies de besouros coprófagos com hábito endocoprídeo escolherem determinadas áreas das massas fecais, justifica-se pelo fato de alimentarem-se e desenvolverem-se dentro destas, onde passam maior parte do seu ciclo de vida. Como as temperaturas podem ser diferentes nas regiões dentro das massas fecais, algumas espécies podem estar procurando local adequado para permanecerem.

As temperaturas médias encontradas na superfície das massas fecais não diferiram das temperaturas tomadas na superficie do solo, enquanto que as temperaturas médias do interior e interface não diferiram da média tomada a um metro de altura no ambiente (Tabela 9). 
Tabela 9. Valores médios de temperaturas $\left({ }^{\circ} \mathrm{C}\right)$ na superficie, interior e interface de massas fecais de quatro idades distintas (MF1, MF2, MF3 e MF4), a um metro de altura e ao nível do solo, durante o período de 01/03 a 25/10/1996. Piracicaba/SP.

\begin{tabular}{ll}
\hline Local & Temperatura ${ }^{0} \mathrm{C}$ \\
\hline MF4 superficie & $20,41 \mathrm{a}^{1}$ \\
Superficie do solo & $20,21 \mathrm{a}$ \\
MF3 superfície & $19,08 \mathrm{ab}$ \\
MF2 superfície & $18,96 \mathrm{abc}$ \\
MF1 superfície & $18,83 \mathrm{abc}$ \\
MF4 interior & $18,76 \mathrm{abc}$ \\
MF1 interface & $17,95 \mathrm{bc}$ \\
MF4 interface & $17,93 \mathrm{bc}$ \\
MF3 interface & $17,86 \mathrm{bc}$ \\
MF1 interior & $17,70 \mathrm{bc}$ \\
MF2 interface & $17,55 \mathrm{bc}$ \\
MF3 interior & $17,40 \mathrm{bc}$ \\
MF2 interior & $17,34 \mathrm{bc}$ \\
Um metro de altura & $17,28 \quad \mathrm{c}$ \\
\hline
\end{tabular}

1 Médias seguidas pela mesma letra não diferem entre si a $5 \%$ de probabilidade, pelo teste de Tukey.

Durante os meses de leitura das temperaturas nas massas fecais e no ambiente, observaram-se que as oscilações térmicas da massas acompanharam as do ambiente (Figuras 5, $6 \mathrm{e}$ 7). Os dados encontrados coincidem com as observações de LANDIN (1961), que afirma que as condições de temperatura das fezes são primariamente determinadas por fatores climáticos, como 

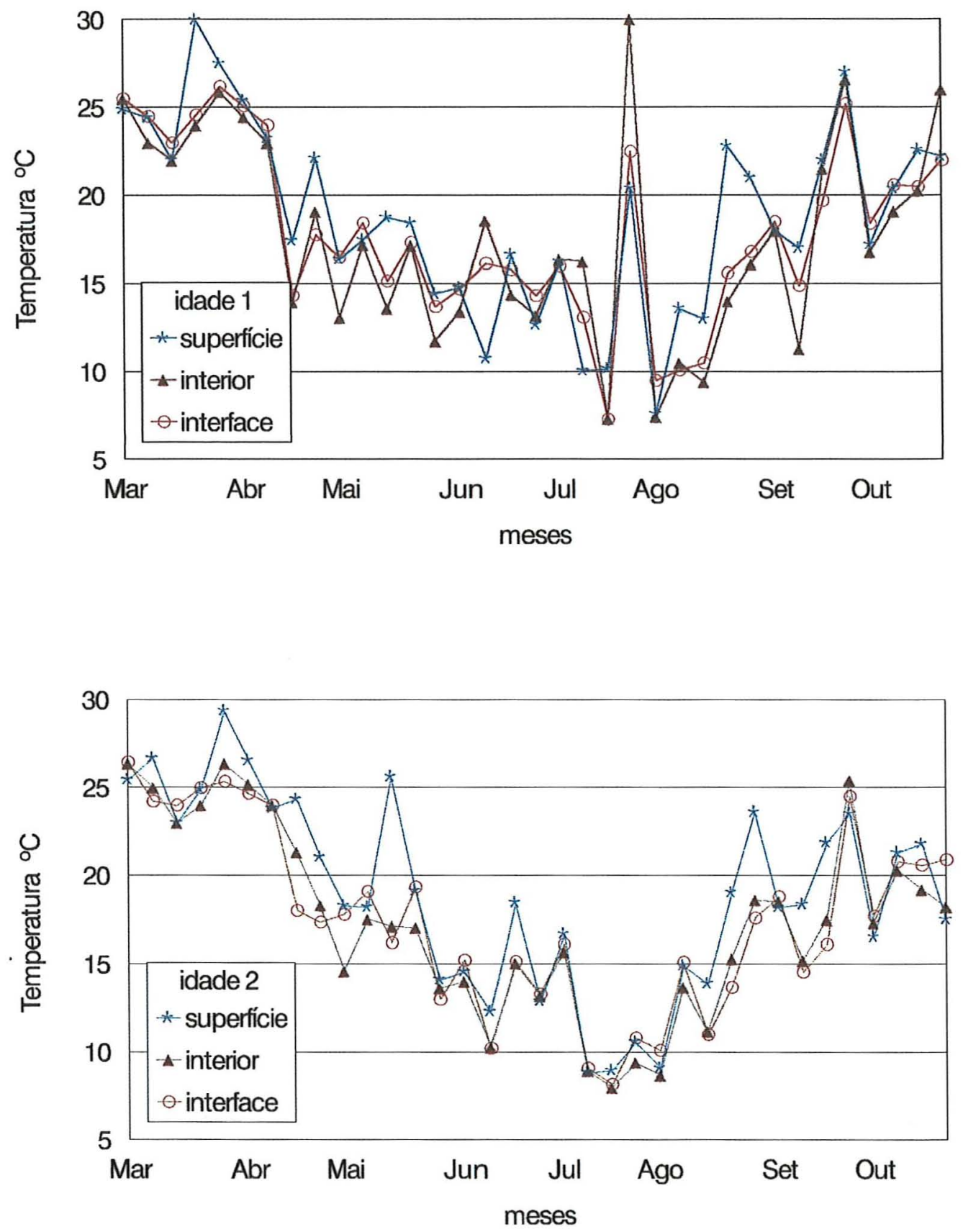

Figura 6. Valores mensais de temperaturas na superfície, interior e interface de massas fecais de idades 1 e 2, durante o período de 01/03 a 25/10/1996. Piracicaba/SP. 

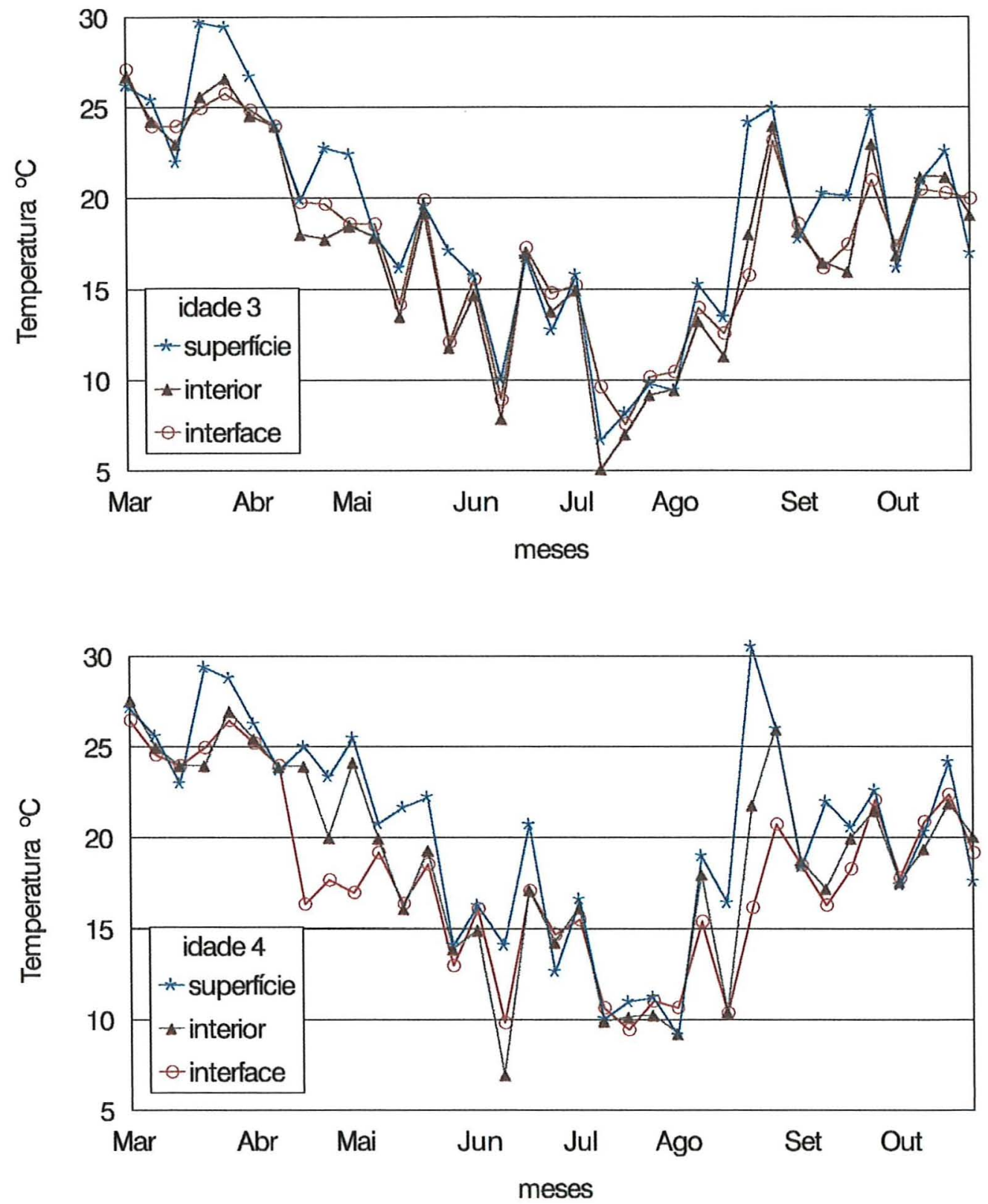

Figura 7. Valores mensais de temperaturas na superfície, interior e interface de massas fecais de idades 3 e 4, durante o período de 01/03 a 25/10/1996. Piracicaba/SP. 
temperatura do ar, umidade, força do vento e insolação.

Nos meses de março a abril observaram-se temperaturas mais elevadas no ambiente, bem como nas massas fecais, enquanto que nos meses de maio a setembro estas foram mais baixas.

os besouros endocoprídeos foram coletados em armadilhas "pitfall" durante praticamente todo período de condução do experimento, como discutido no ítem 4.1.1., mesmo nas épocas mais frias e secas do ano. Provavelmente a ocorrência desse grupo de insetos pode estar relacionada as temperaturas presentes nas massas fecais (que não foram tão baixas), o que permitiu que esse grupo de besouros pudessem utilizar delas para alimentação e desenvolvimento.

A possibilidade de utilização das fezes para alimentação e desenvolvimento pelos besouros de hábito endocoprídeo durante o período frio e seco do ano, torna-se importante, haja vista que durante esse período os besouros paracoprídeos não foram coletados nas armadilhas "pitfall", não havendo portanto incorporação de massas fecais e nem competição por alimento.

\subsubsection{Comportamento em diferentes horários durante o dia}

Em abril (05/04) tomaram-se temperaturas no período da manhã e da tarde $(8: 00$ e 14:00h). Nesse dia as temperaturas nas massas fecais e no ambiente foram elevadas, e na região da superficie das massas fecais observaram-se as maiores temperaturas, independente da idade e horários de leituras, enquanto que os menores valores foram encontrados na região do interior e interface (Figuras 8 e 9).

A leitura da temperatura realizada às $8: 00$ horas, estava em torno de $25^{\circ} \mathrm{C}$ e às $14: 00 \mathrm{~h}$ estava próxima a $40^{\circ} \mathrm{C}$, acompanhando as temperaturas ao nível do solo e a um metro de 

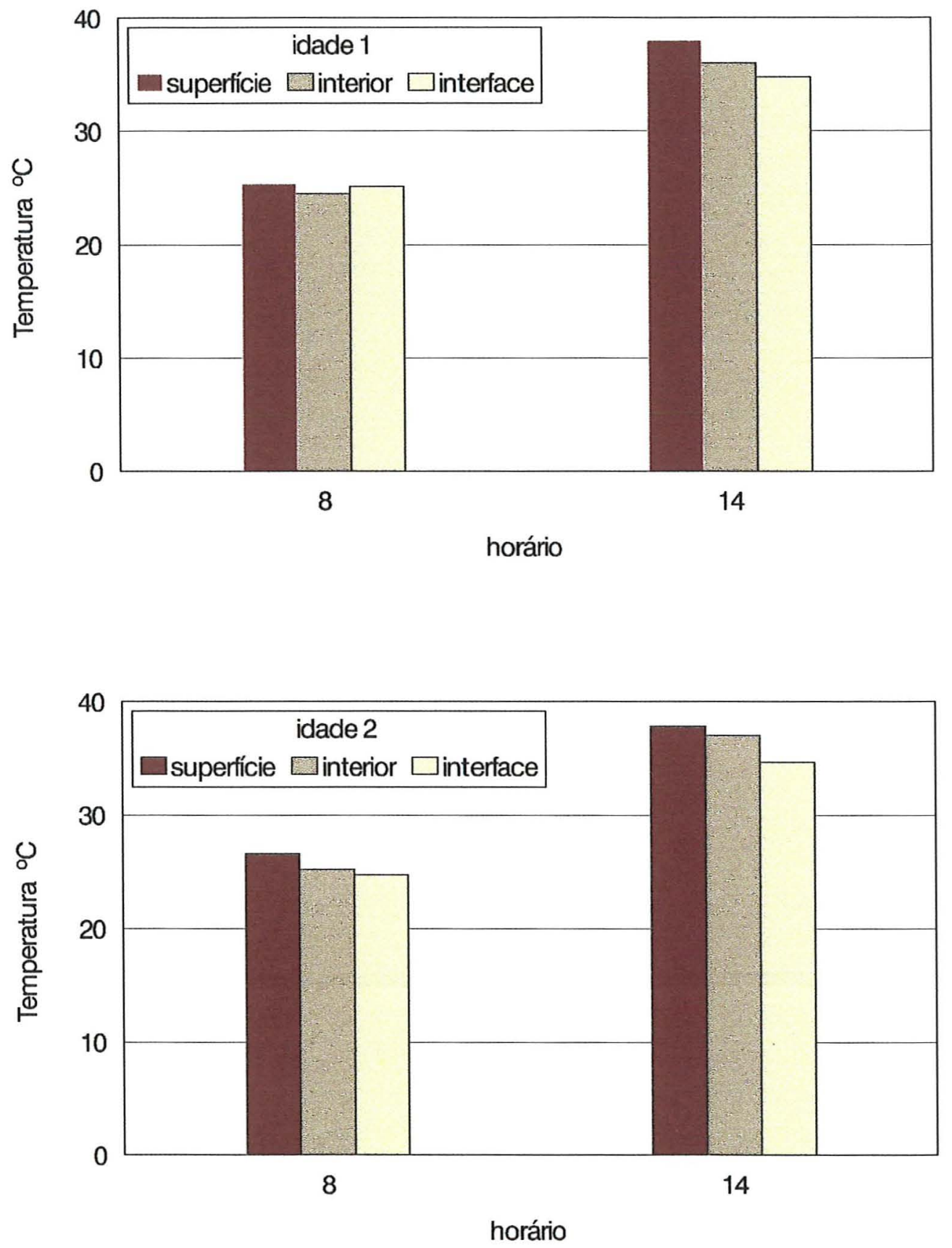

Figura 8. Temperaturas médias na superfície, interior e interface de massas fecais de idades 1 e 2 no dia 05/04/1996, às 8:00 e 14:00 h. Piracicaba/SP. 

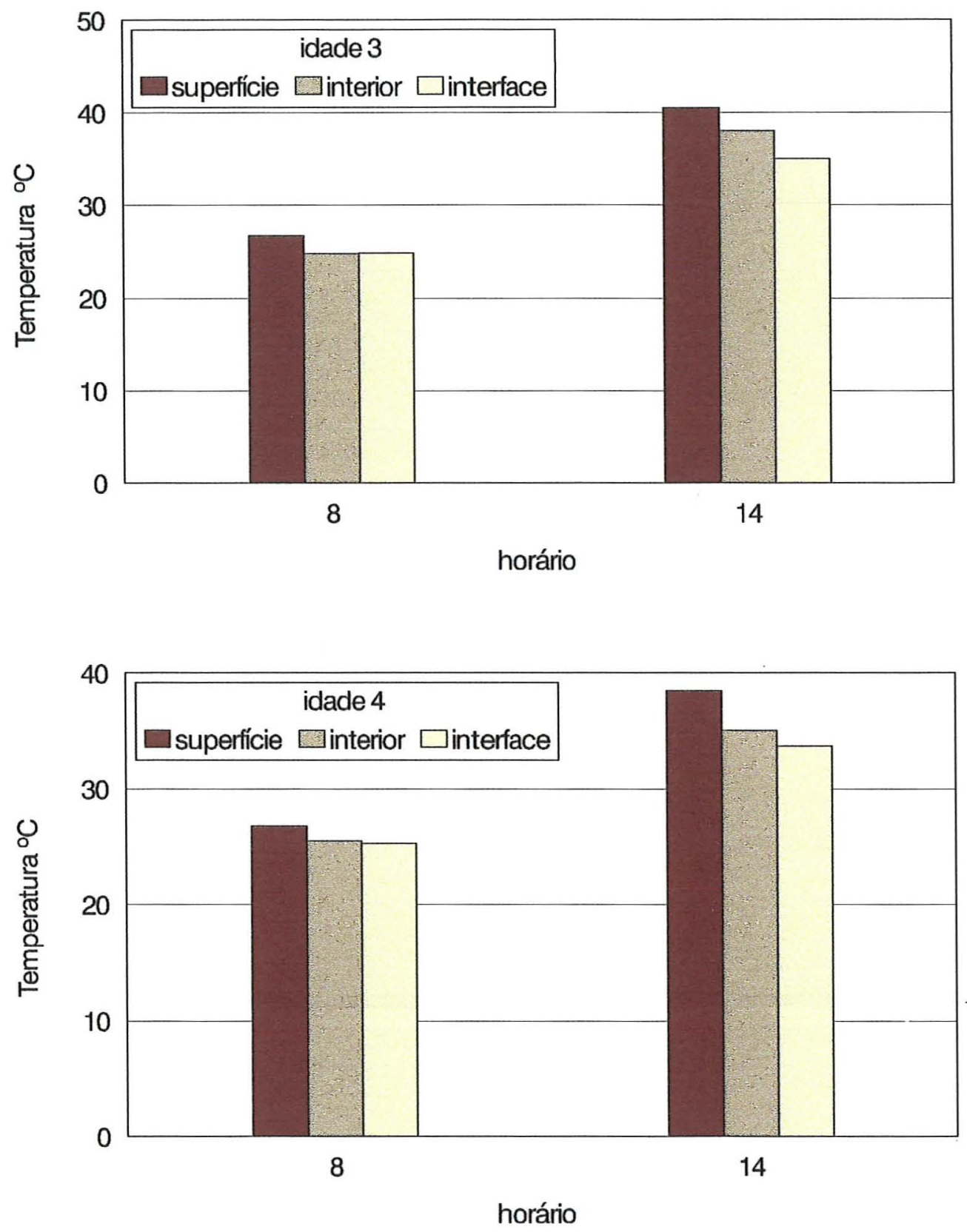

Figura 9. Temperaturas médias na superfície, interior e interface de massas fecais de idades 3 e 4, no dia 05/04/1996, às 8:00 e 14:00 h. Piracicaba/SP. 

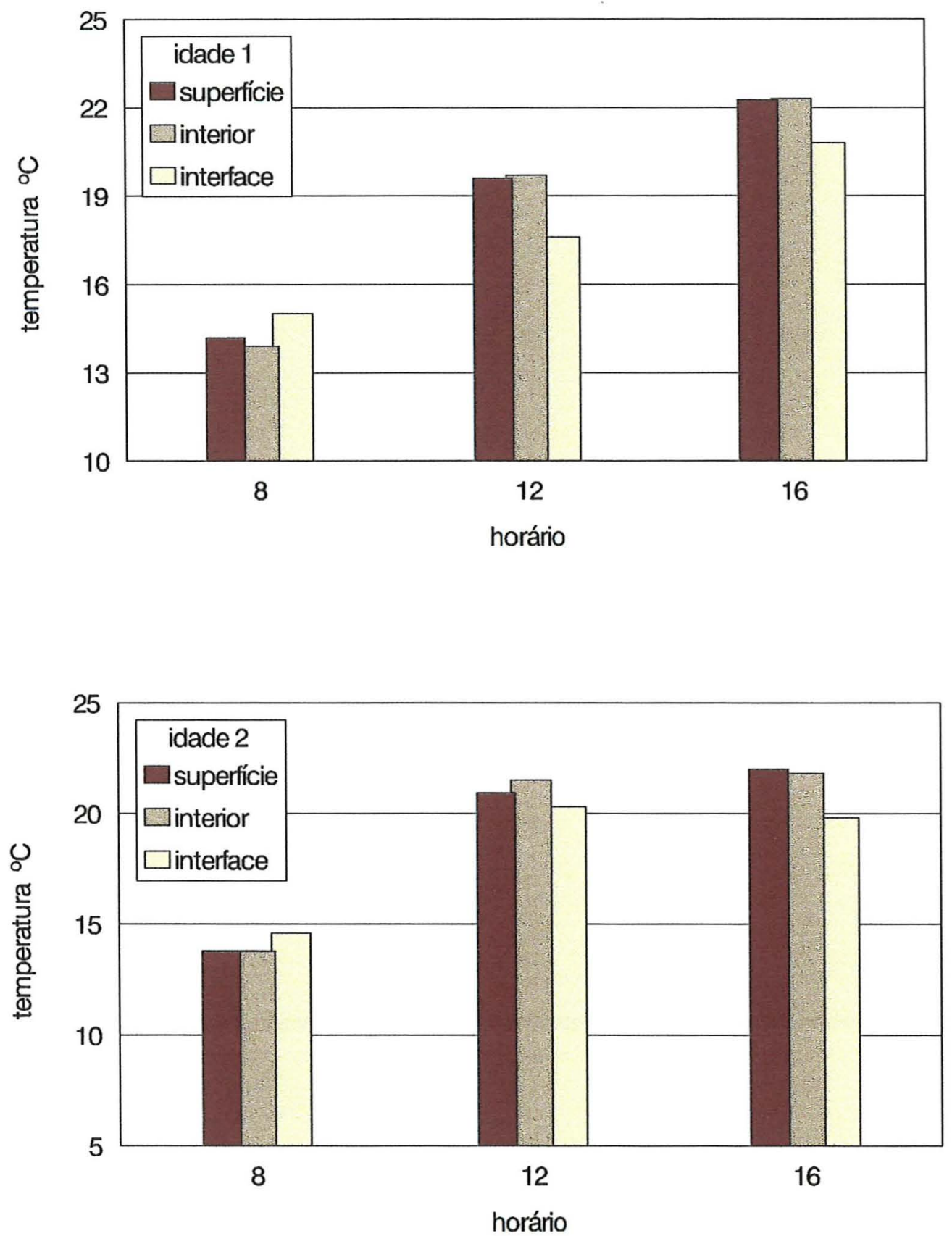

Figura 10. Temperaturas médias na superfície, interior e interface de massas fecais de idades 1 e 2, no dia 06/06/1996, às 8:00, 12:00 e 16:00 h. Piracicaba/SP. 

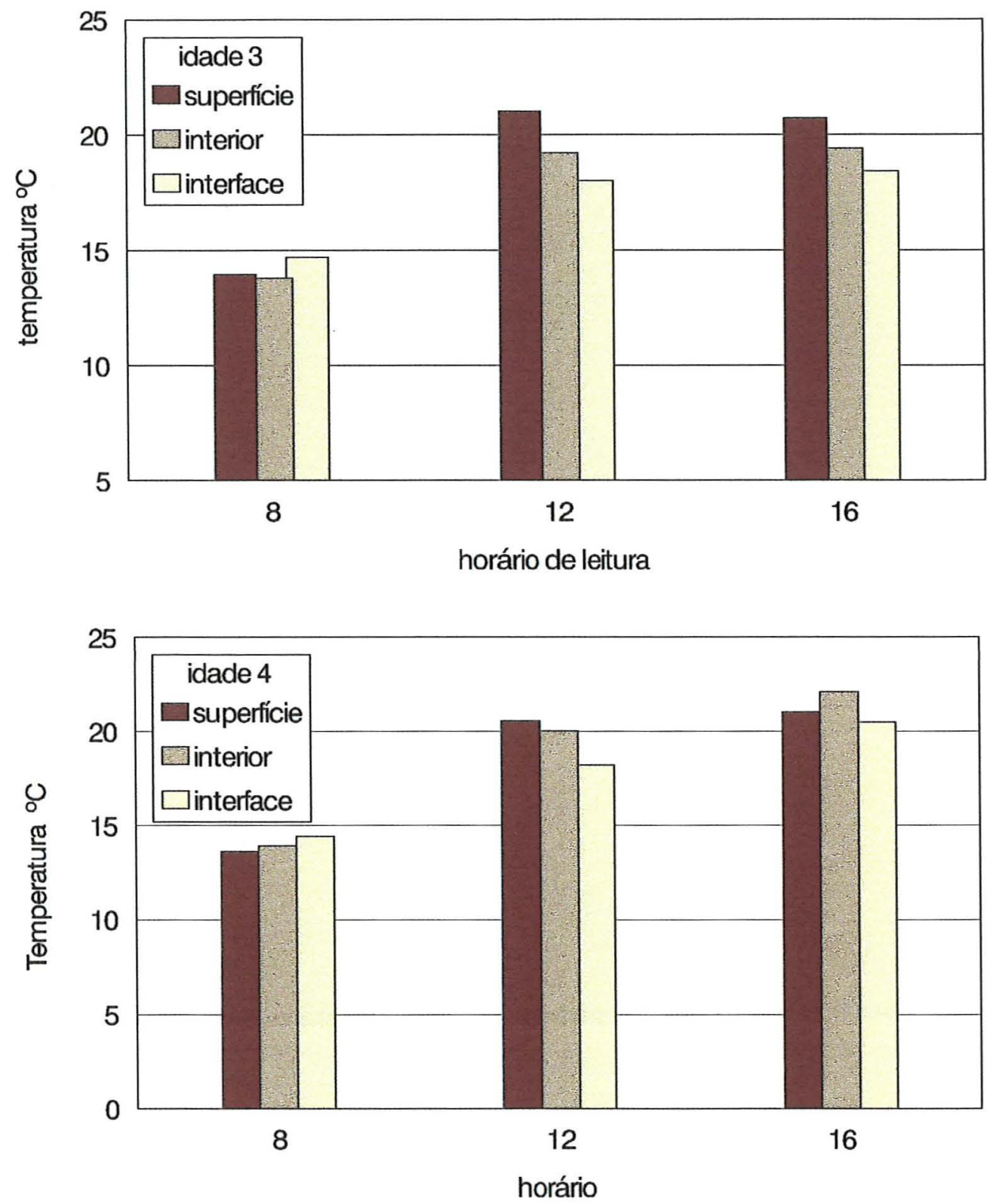

Figura 11. Temperaturas médias na superfície, interior e interface de massas fecais de idades 3 e 4, no dia 06/06/1996, às 8:00, 12:00 e 16:00 h. Piracicaba/SP. 

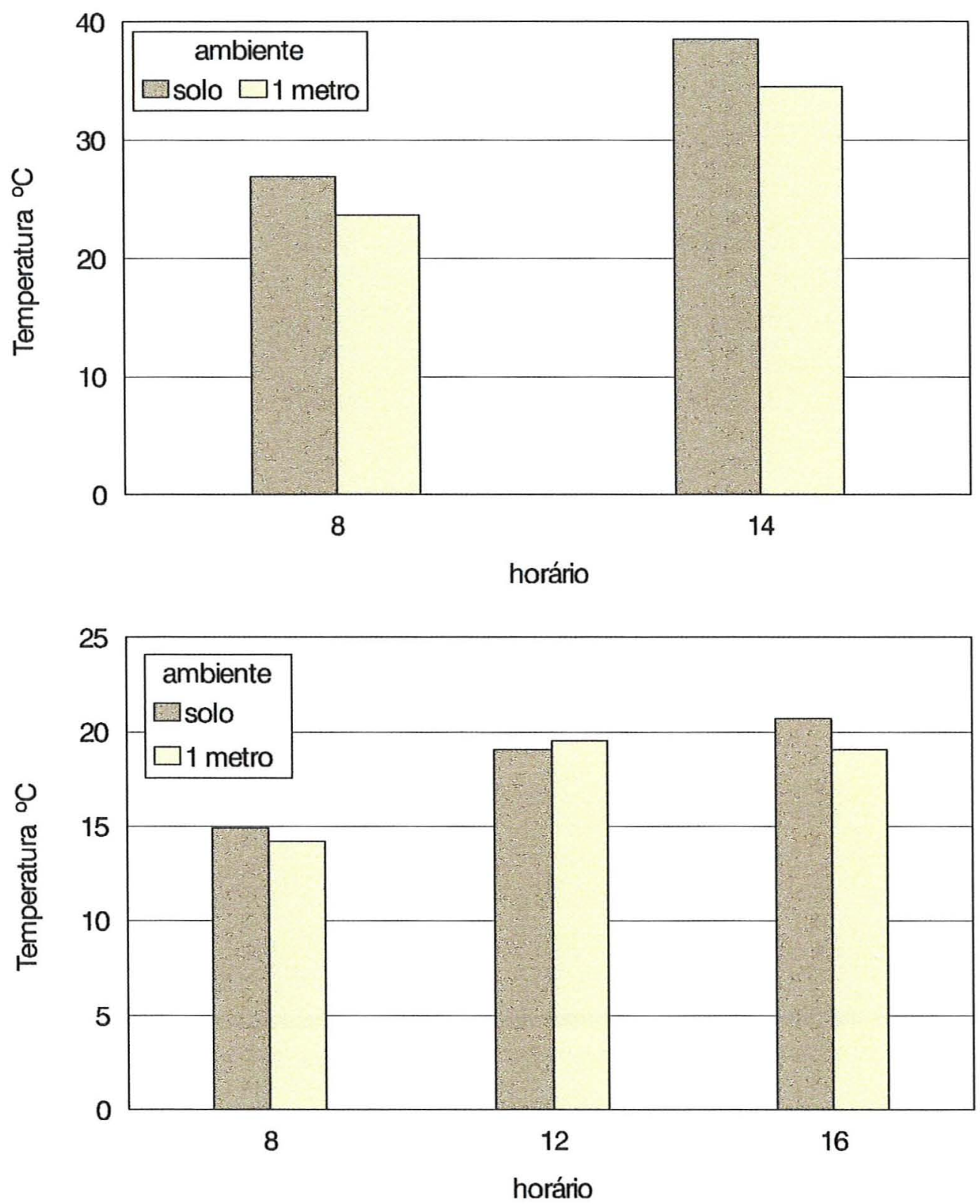

Figura 12. Temperaturas médias na superfície do solo e a um metro de altura na área de pastagem, às 8:00 e 14:00h e 8:00, 12:00 e 16:00h nos dias 05/04 e 06/06/1996, respectivamente. Piracicaba/SP. 
altura. Na superfície da massa fecal de idade 3, às 14:00 horas, a temperatura excedeu $40^{\circ} \mathrm{C}$, sendo essa a maior temperatura encontrada nas massas fecais (Figuras 8, 9 e 12).

Em junho (06/06) as leituras de temperatura foram realizadas em três horários $(8: 00,12: 00$ e 16:00 h) durante o dia, sendo esse um mês de temperaturas baixas, com clima frio e seco.

As temperaturas encontradas neste dia que não excederam $25{ }^{\circ} \mathrm{C}$, foram um pouco diferentes das observadas no mês de abril. Na primeira leitura do dia maiores temperaturas foram observadas na região da interface, da massa fecal com o solo, em todas as idades, e com o passar das horas a superfície e interior da massa fecal ganharam calor apresentando maiores valores do que na região da interface nos demais horários (Figuras 10 e 11).

A coleta de dados em abril e junho, evidenciaram que a massa fecal pode apresentar várias temperaturas durante o dia, sempre acompanhando as oscilações térmicas do ambiente. Dependendo da época do ano, pode-se observar comportamento distinto das temperaturas nas diferentes regiões da massa fecal.

\subsubsection{Previsão de temperaturas em massas fecais}

Como proposto na metodologia realizou-se correlação entre as temperaturas em cada idade de massa fecal com as temperaturas do ambiente de pastagem, encontrando-se alto coeficiente de determinação e probabilidade (Tabela 10). Esses dados mostram que existem relação entre as temperaturas do ambiente com as temperaturas nas massas fecais. 
Tabela 10. Coeficiente de determinação $\left(R^{2}\right)$ e probabilidade entre temperatura média do ambiente de pastagem e massas fecais de quatro idades distintas (MF1, MF2, MF3 e MF4), durante o período de 01/03 a 25/10/1996. Piracicaba/SP.

\begin{tabular}{lll}
\hline Local & \multicolumn{1}{c}{$\mathrm{R}^{2}$} & Probabilidae \\
\hline Ambiente e MF1 & 82,51 & 0,000003 \\
Ambiente e MF2 & 94,24 & 0,000001 \\
Ambiente e MF3 & 95,20 & 0,000001 \\
Ambiente e MF4 & 89,88 & 0,000001 \\
\hline
\end{tabular}

Para as temperaturas da massa fecal de idade 1 , quando correlacionadas com as do ambiente, foi possível a elaboração da seguinte fórmula matemática;

$$
Y=0,807455 X
$$

Onde,

$Y$ = temperatura média da massa fecal de idade 1

$\mathrm{X}$ = temperatura média do ambiente

O coeficiente de determinação $\left(R^{2}\right)$ foi de $68,08 \%$, e probabilidade de 0,00001, para a equação desenvolvida. Para a massa fecal de idade 1 o baixo coeficiente de determinação pode ser explicado, pela temperatura própria que esta apresenta no momento da deposição, a qual se assemelha a do rúmem do bovino. A massa fecal após depositada na pastagem vai alterando sua temperatura. Esse fato não ocorre com as demais idades de massas fecais, pois já estão algumas horas ou dias sobre a superfície das pastagens apresentando ai temperaturas próximas ao do ambiente. 
A temperatura da massa fecal de idade 2, quando correlacionada com a do ambiente foi possível a elaboração da seguinte fórmula matemática;

$$
Y=0,974804 X
$$

Onde, $Y=$ temperatura média da massa fecal de idade 2 $\mathrm{X}$ = temperatura média do ambiente

o coeficiente de determinação $\left(R^{2}\right)$ foi de $88,81 \%$, e probabilidade de 0,00001 , para a equação desenvolvida.

Para massa fecal de idade 3, quando correlacionada com a temperatura do ambiente foi possível a elaboração da seguinte fórmula matemática;

$$
Y=1,061867 X
$$

Onde,

$Y=$ temperatura média da massa fecal de idade 3

$\mathrm{X}=$ temperatura média do ambiente

O coeficiente de determinação $\left(R^{2}\right)$ foi de $90,64 \%$, e probabilidade de 0,00001 , para a equação desenvolvida.

A temperatura da massa fecal de idade 4, quando correlacionada com a do ambiente foi possível a elaboração da seguinte fórmula matemática;

$$
Y=0,937744 X
$$

Onde,

$Y=$ temperatura média da massa fecal de idade 4

$\mathrm{X}$ = temperatura média do ambiente

o coeficiente de determinação $\left(R^{2}\right)$ foi de $80,79 \%$, e 

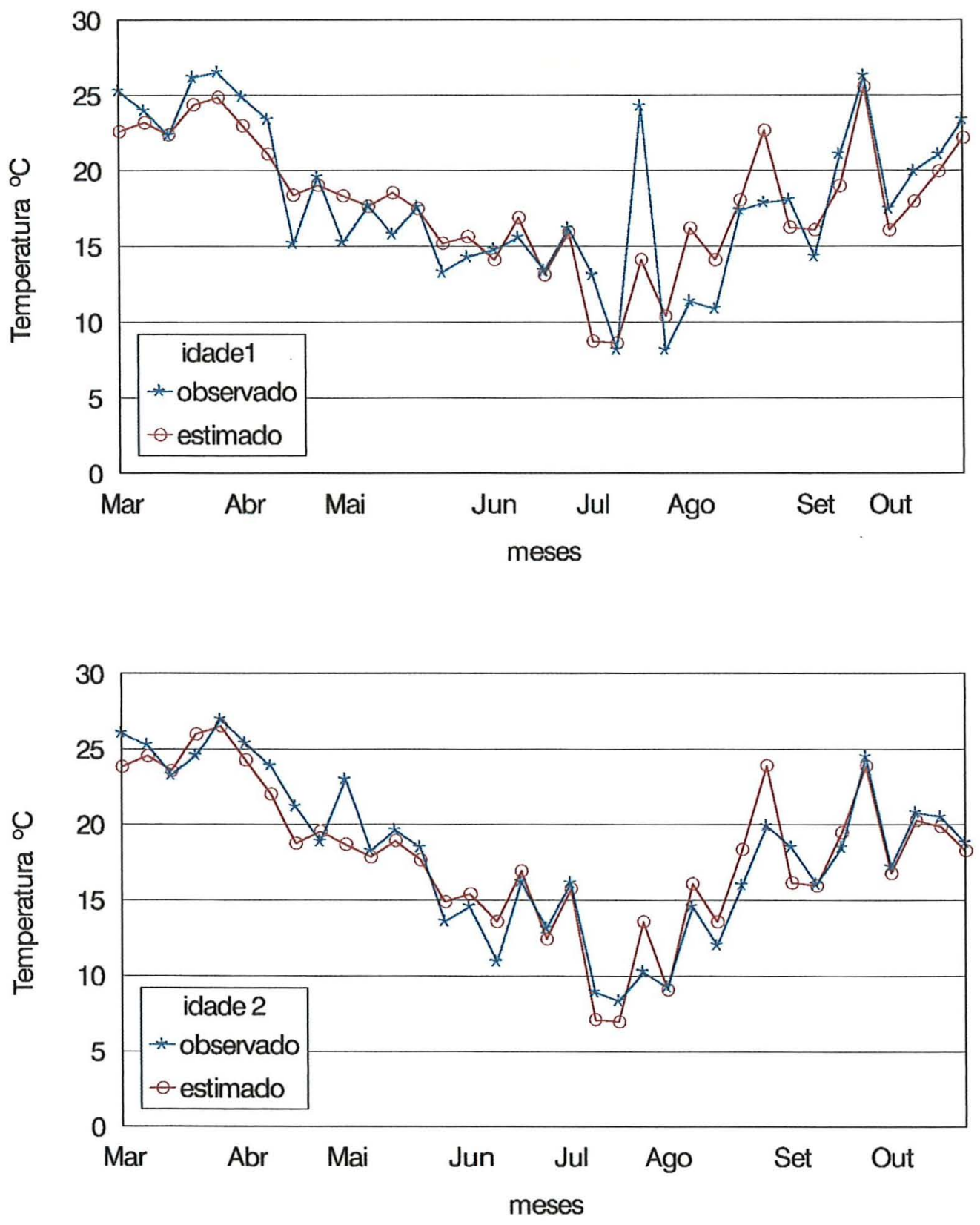

Figura 13. Temperaturas médias reais e estimadas em massas fecais de idades 1 e 2, durante o período de 01/03 a 25/10/1996. Piracicaba/SP. 

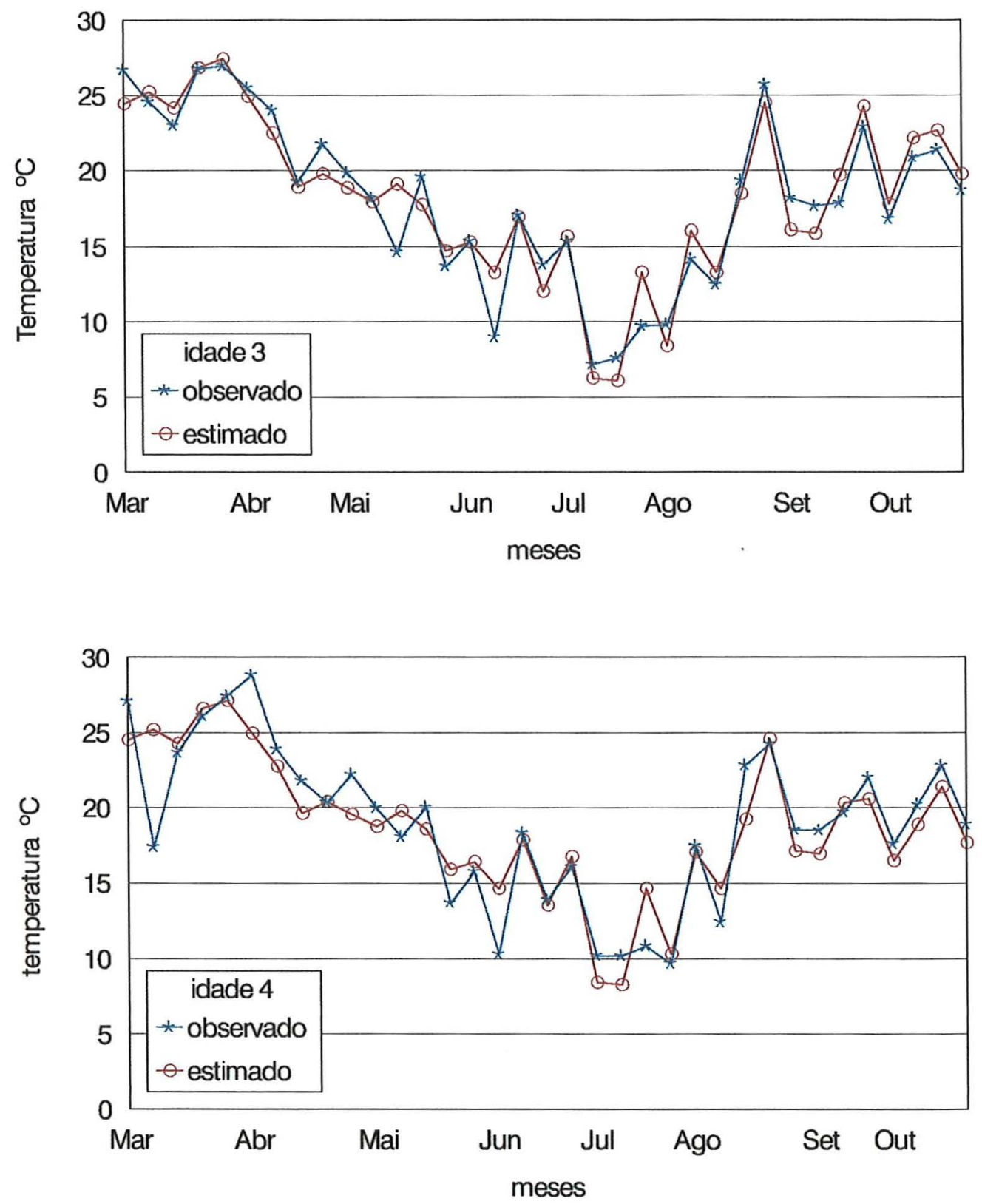

Figura 14. Temperaturas médias reais e estimadas em massas fecais de idades 3 e 4, durante o período de 01/03 a 25/10/1996. Piracicaba/SP. 
probabilidade de 0,00001, para a equação desenvolvida.

Através do uso das fórmulas propostas, pode-se estimar as temperaturas nas massas fecais as quais são muito próximas as temperaturas reais observadas (Figuras 13 e 14). As fórmulas auxiliam a minimizar e agilizar os trabalhos de campo, não havendo mais necessidade de se tomar as temperaturas em cada idade de massa fecal presente na superfície da área de pastagem. Apenas as temperaturas a um metro de altura e ao nível do solo e a obtenção da média entre elas, são suficientes para utilizar nas fórmulas desenvolvidas.

MATTHIESSEN \& PAIMER (1988) correlacionaram temperaturas presentes em um e dois litros de massas fecais com temperatura do ar, horas de insolação, precipitação e fator sasonal, conseguindo elaborar equação para previsão de temperatura em massas fecais.

\subsubsection{Previsão de desenvolvimento de $H$. irritans}

Para o presente estudo é importante que se conheça dados biológicos de $H$. irritans. Alguns estudos foram realizados em diferentes temperaturas, obtendo-se uma variação da fase de ovo a adulto de 9 a 29 dias (MELVIN \& BECK, 1931; HONER et al., 1990) (Tabela 11).

Tabela 11. Período de desenvolvimento da fase de ovo a adulto de $H$. irritans, mantido em diferentes temperaturas $\left({ }^{\circ} \mathrm{C}\right)$ ( MELVIN \& BECK, 1931; HONER et al., 1990).

\begin{tabular}{cc}
\hline Temperatura ${ }^{0} \mathrm{C}$ & Dias de duração \\
\hline 18 & 29,0 \\
25 & 14,0 \\
30 & 9,9 \\
33 & 9,0 \\
\hline
\end{tabular}


Através desses dados foi possível elaborar o cálculo das necessidades térmicas dessa mosca, encontrando-se a temperatura base de $11,32^{\circ} \mathrm{C}$ e constante térmica de 190,97 graus dias (Tabela 12) (Figura 15).

Foi possível ainda a elaboração de equação, onde pode-se estimar a velocidade de desenvolvimento da mosca, sendo a fórmula expressada por;

$$
1 / D=-0,059260+0,005237 x
$$

Onde;

$1 / D=$ dias de desenvolvimento

$\mathrm{X}$ = temperatura do substrato onde desenvolve-se a fase imatura

Conhecendo-se as exigências térmicas de $H$. irritans torna-se um tanto mais fácil de se conhecer o comportamento durante os meses do ano.

As massas fecais de bovinos, após a deposição na área de pastagem, vão perdendo umidade passando por quatro distintas idades até ressecarem completamente (FLECHTMANN et al., 1995b).

Tabela 12. Limite térmico inferior de desenvolvimento (Tb), constante térmica (K) e coeficiente de determinção $\left(\mathrm{R}^{2}\right)$ de H. irritans.

\begin{tabular}{cccc}
\hline Espécie & $\mathrm{Tb}\left({ }^{\circ} \mathrm{C}\right)$ & $\mathrm{K}(\mathrm{GD}){ }^{1}$ & $\mathrm{R}^{2}$ \\
\hline H. irritans & 11,32 & 190,97 & 99,90 \\
\hline $1_{\mathrm{GD}}=$ Graus-dia & & &
\end{tabular}




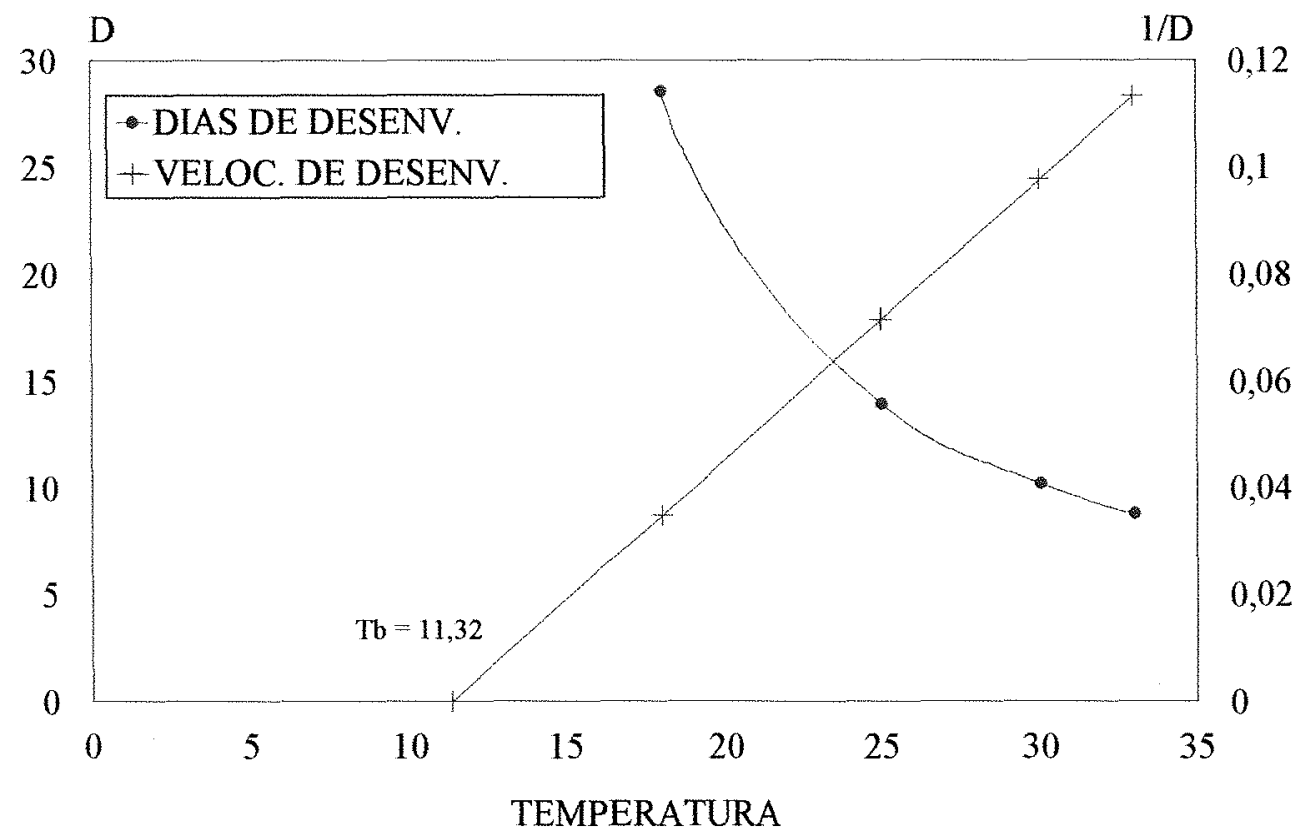

Figura 15. Curva de velocidade de desenvolvimento de $H$. irritans em diferentes temperaturas.

Os ovos de $H$. irritans são depositados em massas recém excretadas de idade 1 , as quais dentro de algumas horas começam a perder umidade, atingindo idade 2; pode ainda neste estágio não ter ocorrido a eclosão das larvas. No momento da eclosão das larvas, a massa fecal já de idade 2 continua perdendo umidade e dentro de alguns dias atinge idade 3, enquanto que as larvas de moscas poderão estar no segundo ou terceiro ínstar. Quando as massas fecais atingirem idade 4, pode-se encontrar no seu interior pupas recém formadas. Dessa forma todo o período da fase de ovo a pupa pode ocorrer em uma massa fecal que passa pelas quatro distintas idades. É possivel ainda ter o desenvolvimento de ovo a larva de terceiro ínstar em massas fecais de idades 1 a 3 e a pupa no solo. 
Tabela 13. Médias mensais de temperaturas $\left({ }^{\circ} \mathrm{C}\right)$ em quatro distintas idades de massas fecais (MF1, MF2, MF3 e MF4), e dias necessários para o desenvolvimento de uma geração de $H$. irritans, durante o período de 01/03 a 25/10/1996. Piracicaba/SP.

\begin{tabular}{|c|c|c|c|c|c|c|}
\hline \multirow[b]{2}{*}{ Meses } & \multicolumn{5}{|c|}{ Temperaturas ${ }^{0} \mathrm{C}$} & \multirow{2}{*}{$\begin{array}{c}\text { Dias para o } \\
\text { desenvolvimento } \\
\text { de uma geração }\end{array}$} \\
\hline & MF1 & MF2 & MF3 & MF4 & médias & \\
\hline Março & 24,87 & 25,27 & 25,60 & 25,88 & 25,41 & 13,55 \\
\hline Abril & 20,82 & 22,39 & 22,62 & 22,97 & 22,20 & 17,54 \\
\hline Maio & 15,96 & 17,38 & 17,19 & 18,80 & 17,33 & 31,57 \\
\hline Junho & 14,54 & 13,72 & 13,79 & 14,58 & 14,16 & 67,13 \\
\hline Julho & 15,47 & 10,93 & 9,97 & 11,84 & 12,05 & 260,02 \\
\hline Agosto & 13,19 & 14,36 & 15,97 & 17,34 & 15,22 & 48,91 \\
\hline Setembro & 17,85 & 17,68 & 17,91 & 18,89 & 18,08 & 28,23 \\
\hline Outubro & 20,52 & 19,34 & 19,45 & 19,90 & 19,80 & 22,51 \\
\hline
\end{tabular}

Durante 0 experimento foram coletados dados de temperatura em massa fecal de diferentes idades, e a $5 \mathrm{~cm}$ de profundidade no solo. Esses valores foram utilizados na fórmula elaborada, para o cálculo da velocidade de desenvolvimento de H. irritans, e assim, pôde-se prever o número de gerações por mês (Tabelas 13 e 14).

Como observado nos meses mais quentes do ano as temperaturas nas massas fecais são mais elevadas, permitindo assim acúmulo de maior quantidade de graus dias à $H$. irritans. Nos meses de março e abril, haverá acúmulo de 14,09 e 10,88 graus dia, o que levará a formação de cerca de quatro gerações nesse período, necessitando assim de medidas mais intensas de controle dessa mosca. 
Tabela 14. Médias mensais de temperaturas $\left({ }^{\circ} \mathrm{C}\right)$ em três idades distintas de massas fecais (MF1, MF2 e MF3), a cinco centrimetros de profundidade no solo e dias necessários para o desenvolvimento de uma geração de H. irritans, durante o período de 09/08 a 25/10/1996. Piracicaba/SP.

\begin{tabular}{|c|c|c|c|c|c|c|}
\hline \multirow[b]{2}{*}{ Meses } & \multicolumn{5}{|c|}{ Temperaturas ${ }^{0} \mathrm{C}$} & \multirow{2}{*}{$\begin{array}{c}\text { Dias para o } \\
\text { desenvolvimento } \\
\text { de uma geração }\end{array}$} \\
\hline & MF1 & MF2 & MF3 & $5 \mathrm{~cm}$ & médias & \\
\hline Agosto & 13,19 & 14,36 & 15,97 & 17,89 & 15,35 & 47,33 \\
\hline Setembro & 17,85 & 17,68 & 17,91 & 19,83 & 18,32 & 27,26 \\
\hline Outubro & 20,52 & 19,34 & 19,45 & 21,10 & 21,10 & 19,52 \\
\hline
\end{tabular}

Nos meses de maio a setembro o acúmulo de graus dias seriam de $6,01,2,84,0,73,3,9$ e 6,76 respectivamente, e provavelmente haveria a formação de cerca de três gerações nesse período.

No mês de outubro, com o aumento da temperatura ambiente, haveria acúmulo de 8,48 graus dia, levando a formação de uma geração e meia de $H$. irritans. 


\section{CONCLUSÕES}

- A espécie Dichotomius anaglypticus é a principal incorporadora de massa fecal na área de pastagem;

- O microclima da pastagem apresenta temperaturas mais elevadas e com maiores oscilações;

- As temperaturas das massas fecais acompanham as temperaturas do ambiente;

- Massas fecais mais velhas apresentam temperaturas mais elevadas;

- Massas fecais no período frio e seco do ano apresentam condições de serem exploradas por insetos fimícolas;

- As fórmulas de previsão da temperatura da massa fecal de idade $1,2,3$ e 4 são respectivamente: 0,807455x; 0,974804x; $1,061867 x ; 0,937744 x$;

- De março a outubro haverá a formação de cerca de oito gerações e meia de Haematobia irritans. 
REFERÊNCIAS BIBLIOGRÁFICAS

ALVES, S.B. Escarabeídeos da fauna fimícola das pastagens da região de Piracicaba-SP. In: CONGRESSO BRASILEIRO DE ENTOMOLOGIA, 3, Maceió, 1976. Resumos. Maceió: 1976, p.103-104.

ALVES, S.B. Biologia e importância econômica do Dichotomius anaglypticus (Mannerheim, 1829) (Coleoptera, Scarabaeidae). Piracicaba, 1977. 72p. Dissertação (Mestrado) - Escola Superior de Agricultura "Luiz de Queiroz", Universidade de São Paulo.

ALVES, S.B.; NAKANO, O. Estudo da biologia do Dichotomius anaglypticus (Mannerheim, 1829) (Coleoptera, Scarabaeidae). Ecossistema, v.3, n.3, p.11-20, 1978.

AVILA, J.M.; FERNÁNDEZ-SIGLER, A. Influencia de la textura del excremento en la distribución y abundancia de algunas especies de escarabeidos coprófagos en el sur de la Península Ibérica (Coleoptera, Scarabaeoidea). Elytron, v.2, p.27-35, 1988 .

BAZ, A. Selección de macrohábitat por algunas especies y análisis de una comunidad de escarrabeidos coprófagos (Coleoptera) del macizo de Ayllón (sistema central, Espana). Annales de la Société Entomologique de France, v.24, n.2, p.203-210, 1988. 
BLUME, R.R. Euoniticellus intermedius (Coleoptera: Scarabaeidae): Description of adults and immatures and biology of adults. Environmental Entomology, v.13, n.4, p.1064-1068, 1984 .

BLUME, R.R.; AGA, A. Phanaeus difformis Leconte (Coleoptera: Scarabaeidae): clarification of published descriptions, notes on biology, and distribution in Texas. The Coleopterists Bulletin, v.30, n.2, p.199-205, 1976.

BORNEMISSZA, G.F. Insectary studies on the control of dung breeding flies by the activity of the dung beetle, Onthophagus gazella F. (Coleoptera: Scarabaeinae). Journal of the Australian Entomological Society, v.9, n.1, p.31-41, 1970 .

BRUSSAARD, L. Reproductive behaviour and development of the dung beetle Typhaeus typhoeus (Coleoptera, Geotrupidae). Tijdschriff voor Entomologie, v.126, n.10, p.203-231, 1983.

BRYAN, R.P. The effects of dung beetle activity on the numbers of parasitic gastrointestinal helminth larvae recovered from pasture samples. Australian Journal of Agricultural Research, v.24, n.1, p.161-168, 1973.

BRYAN, R.P. The effect of dung beetle, Onthophagus gazella, on the ecology of the infective larvae of gastrointestinal nematodes of cattle. Australian Journal of Agricultural Research, v.27, n.4, p.567-574, 1976.

COLLARES, N.C.P.; LEITE, R.C. Alguns aspectos etológicos da Haematobia irritans em Roraima. Arquivo Brasileiro de Medicina Veterinária e Zootecnia, v.44, n.2, p.157-158, 1992. 
D'OLSOUFIEFF, $G$. Les phaneides (Coleoptera-Lamellicornia) família Scarabaeidae - Tr. Coprini. Insecta, V.13, n.145/156, p.1-172, 1924.

DOUBE, B.M. Biological control of the buffalo fly in Australia: The potencial of the Southern Africa dung fauna. Miscellaneous Publications of the Entomological Society of America, n.61, p.16-34, 1986.

DOUBE, B.M.; MOOLA, F. The effect of the activity of the African dung beelte Catharsius tricornutus De Geer (Coleoptera: Scarabaeidae) on the survival and size of the African buffalo fly, Haematobia thirouxi potans (Bezzi) (Diptera: Muscidae), in bovine dung in the laboratory. Bulletin of Entomological Research, v.78, n.1, p.63-73, 1988 .

DOUBE, B. M.; GILLER, P.S.; MOOLA, F. Dung burial strategies in some South African coprine and onitine dung beetles (Scarabaeidae: Scarabaeinae). Ecological Entomology, v.13, n.3, p.251-261, 1988 .

DUDLEY, C.O. Insects of the floodplain. 3. The dung beetles of the western grasslands of the Chilwa area. Monographiae Biologicae, v.35, p.285-290, 1979.

EDWARDS, P.B. Development and larval diapause in the southern African dung beetle Onitis caffer Boheman (Coleoptera: Scarabaeidae). Bulletin of Entomological Research, v.76, n.1, p.109-117, 1986.

EDWARDS, P.B.; ASCHENBORN, H.H. Patterns of nesting and dung burial in onitis dung beetles: implications for pasture productivity and fly control. Journal of Applied Ecology, v.24, n.3, p.837-851, 1987. 
EDWARDS, P.B.; ASCHENBORN, H.H. Male reproductive behaviour of the African ball-roling dung beetle, Kheper nigroaeneus (Coleoptera: Scarabaeidae). The Coleopterists Bulletin, v.42, n.1, p.17-27, 1988.

FAO QUARTERLY BULLETIN OF STATISTICS - 1995, v.8, n.3/4, p.51, 1995.

FAzOLIN, M. Análise faunística de insetos coletados com armadilha luminosa em seringueira no Acre. Piracicaba, 1991. 236p. Tese (Doutorado) - Escola Superior de Agricultura "Luiz de Queiroz", Universidade de São Paulo.

FERREIRA, E.R. Haematobia irritans, Dira, 7 p. (s.d.).

FERREIRA, A.M.R.M.; GALILEO, M.H.M. Revisão taxonômica do gênero Pedaridium Harold, 1868 (Coleoptera, Scarabaeidae, Scarabaeinae, Coprini). Iheringia, v.74, p.3-69, 1993.

FINCHER, G.T. Dung beetles as biological control agents for gastrointestinal parasites of livestock. The Journal of Parasitology, v.59, n.2, p.369-399, 1973.

FINCHER, G.T. Effect of dung beetle activity on the number of nematode parasites acquired by grazing cattle. The Journal of Parasitology, v.61, n.4, p.759-762, 1975.

FINCHER, G.T. Sustained-release bolus for horn fly (Diptera: Muscidae) control: effects of methoprene and diflubenzuron on some nontarget species. Environmental Entomology, v.20, n.1, p.77-82, 1991. 
FLECHTMANN, C.A.H.; RODRIGUES, S.R. Insetos fimícolas associados a fezes bovinas em Jaraguá do Sul/SC. 1. Besouros coprófagos (Coleoptera, Scarabaeidae). Revista Brasileira de Entomologia, v.39, n.2, p.303-309, 1995.

FLECHTMANN, C.A.H.; RODRIGUES, S.R.; COUTO, H.T.Z. Controle Biológico da mosca-dos-chifres (Haematobia irritans irritans) em Selvíria, Mato Grosso do Sul. 2. Ação de insetos fimicolas em massas fecais no campo. Revista Brasileira de Entomologia, v.39, n.2, p.237-247, 1995a.

FLECHTMANN, C.A.H.; RODRIGUES, S.R.; SENO, M.C.Z. Controle biológico da mosca-dos-chifres (Haematobia irritans irritans) em Selvíria/MS, Mato Grosso do Sul. 1. Metodologia de estudo e seleção de fauna fimícola de insetos. Revista Brasileira de Entomologia, v.39, n.1, p.1-11, 1995b.

FLECHTMANN, C.A.H.; RODRIGUES, S.R.; ARAÚJO, S.D.; WENZEL, R.I. Levantamento de insetos fimícolas em Ilha Solteira, São Paulo, Brasil. Revista Brasileira de Entomologia, v.39, n.1, p.115-120, $1995 \mathrm{c}$.

GALBIATI, C.; BENSI, C.; CONCEIÇÃO, C.H.C.; FLORCOVSKI, J.L; CALAFIORI, M.H. Estudo comparativo entre besouros do esterco, Dichotomius anaglypticus (Mann., 1829) e Onthophagus gazella (F.), sobre as pastagens, em condições brasileiras. Ecossistema, v.20, p.109-118, 1995.

GOMES, A.; KOLLER, W.W.; FLECHTMANN, C.A.H.; RODRIGUES, S.R.; BIANCHIN, I.; HONER, M.R. Coleópteros fimícolas associados a massas fecais de bovinos em Campo Grande, MS. In: CONGRESSO DE ENTOMOLOGIA, 15., Caxambu, 1995. Resumos. Caxambu: SEB, 1995. p.585. 
GONÇALVES, M.C.V. A maior praga do gado infesta o Brasil. Casa da Agricultura, v.12, n.1, p.12-17, 1990.

GRISI, L.; SCOTT, F.B. Susceptibilidade de populações da mosca do chifre Haematobia irritans à inseticidas no Estado de São Paulo. In: SEMINÁRIO BRASILEIRO DE PARASITOLOGIA VETERINÁRIA; SIMPÓSIO SOBRE A MOSCA-DOSCHIFRES (Haematobia irritans), São Paulo, 1991. Anais. São Paulo: 1991. p.150-152.

GRONVOLD, J.; SOMMER, C.; HOLTER, P.; NANSEN, P. Reduced splash dispersal of bovine parasitic nematodes from cow pats by the dung beetle Diastellopalpus quinquedens. Journal of Parasitology, v.78, n.5, p.845-848, 1992.

GUIMARÃES, J.H. A Haematobia irritans no Brasil, biologia, importância econômica e controle. In: SIMPósIo INTERNACIONAL SOBRE A MOSCA-DOS-CHIFRES Haematobia irritans, 1, São Paulo, 1990. Anais. São Paulo: 1990. p.17-19.

HADDAD, M.L. \& PARRA, J.R.P. Métodos para estimar os limites térmicos e a faixa ótima de desenvolvimento das diferentes fases do ciclo evolutivo dos insetos. Piracicaba: FEALQ, 1984. 12p. (Série Agricultura e Desenvolvimento).

HALFFTER, G. Feeding, bisexual cooperation and subsocial behaviour in three groups of Coleoptera. Advances in Coleopterology, p. 281-96, 1991a.

HALFFTER, G. Historical and ecological factors determining the geographical distribution of beetles (Coleoptera: Scarabaeidae: Scarabaeinae). Folia Entomológica Mexicana, n.82, p.195-238, $1991 b$. 
HALFFTER, G.; MATTHEWS, E.G. The natural history of dung beetles, of the sub-family Scarabaeinae (Coleoptera: Scarabaeidae). Folia Entomologica Mexicana, n.12/14, p.1$312,1966$.

HALFFTER, G.; FAVILA, M.E.; HALFFTER, V. A comparative study of the structure of the scarab guild in mexican tropical rain forests and derived ecosystems. Folia Entomológica Mexicana, n.84, p.131-156, 1992 .

HALFFTER, G.; HALFFTER, V.; HUERTA, C. Mating and nesting behaviour of Eurysternus (Coleoptera: Scarabaeinae). Quaestiones Entomologicae, v.16, n.3/4, p. 597-620, 1980.

HALFFTER, G.; HALFFTER, V. LOPEZ G., I. Phanaeus behaviour: food transportation and bisexual cooperation. Environmental Entomology, v.3, n.2, p.341-345, 1974.

HANSKI, I. The community of coprophagous beetles (Coleoptera, Scarabaeidae and Hydrophilidae) in northern Europe. Annales Entomologici Fennici, v.46, n.3, p.57-73, 1980.

HARRIS, R.L.; MILLER, J.A.; FRAZAR, E.D. Hornflies and stableflies activity. Annals of the Entomological Society of America. v.67, p.891-894, 1974.

HEINRICH, J.E.; BARTHOLOMEW, G.A. The ecology of the african dung beetle. Scientific American, v.24, n.5, p.118-126, 1979.

HILLERTON, J.E.; BRAMLEY, A.J.; YARROW, N.H. O controle da mosca-do-chifre: em novilhas de raça leiteira. A Hora veterinária, v.10, n.55, p.7-12, 1990. 
HOLTER, P. Resource utilization and local coexistence in a guild of scarabaeid dung beetles (Aphodius spp.). Oikos, v.39, n.2, p.213-227, 1988.

HOLTER, P. Abundance and reproductive strategy of dung beetle Aphodius rufipes (L.) (Scarabaeidae). Ecological Entomology, v.4, n.4, p.317-326, 1979.

HONER, M.R.; GOMES, A. O manejo integrado de mosca dos chifres, berne e carrapato em gado de corte. Campo Grande : EMBRAPACNPGC, 1990. 60p. (EMBRAPA-CNPGC. Circular Técnica, 22).

HONER, M.R.; BIANCHIN, I.; GOMES, A. Desenvolvimento de um programa integrado de controle dos nematódeos e a mosca dos chifres na região dos cerrados: Fase 2: Observações sobre a dinâmica populacional dos besouros coprófagos autóctones. Campo Grande : EMBRAPA-CNPGC, 1988. 5p. (EMBRAPA-CNPGC. Pesquisa em Andamento, 40).

HONER, M.R.; BIANCHIN, I.; GOMES, A. Mosca-dos-chifres: histórico, biologia e controle. Campo Grande: EMBRAPA-CNPGC, 1990. 34p. (EMBRAPA-CNPGC. Documentos, 45).

HOWDEN, H.F. \& NEALIS, V.G. Effects of clearing in a tropical rain forest on the composition of the coprophagous scarab beetle fauna (Coleoptera). Biotropica, v.7, n.2, p.77-83, 1975.

HUGHES, R.D.; TYNDALE-BISCOE, M.; WALKER, J. Effects of introduced dung beetles (Coleoptera: Scarabaeidae) on the breeding and abundance of the Australian bushfly, Musca vetustissima Walker (Diptera:Muscidae). Bulletin of Entomological Research, v.68, n.3, p.361-372, 1978. 
JESSOP, I. An identification guide to Eurysternine dung beetles (Coleoptera, Scarabaeidae). Journal of Natural History, v.19, n.6, p.1087-1111, 1985.

KEY, R.S. Cluster analysis of dung inhabiting beetle communities from different altitudes in Jostedalen, SouthWest Norway. Fauna Norvegica Series B: Norwegian Journal of Entomology, v.29, n.1, p.24-33, 1982.

KINGSTON, T.J.; COE, M. The biology of a giant dung-beetle (Heliocopris dilloni) (Coleoptera: Scarabaeidae). Journal of zoology, v.181, n.2, p.243-263, 1977.

KIRK, A.A.; WALLACE, M.M.H. Seasonal variations in numbers, biomass and breeding patterns of dung beetles (Coleoptera: Scarabaeidae) in Southern France. Enthomophaga, v.35, n.4, p.569-581, 1990 .

KLEIN, B.C. Effects of forest fragmentation on dung and carrion beetle communities in central Amazonia. Ecology, v.70, n.6, p.1715-1725, 1989.

KOHLMANN, B. Biosistemática de las especies norteamericanas del género Ateuchus (Coleoptera: Scarabaeidae: Scarabaeinae). Folia Entomológica Mexicana, n.60, p.1-81, 1984 .

KRAFSUR, E.S.; ERNST, C.M. Phenology of horn fly populations (Diptera: Muscidae) in Iowa, USA. Journal of Medical Entomology, v.23, n.2, p.188-195, 1986.

LANDIN, B.O. Ecological studies on dung-beetles. Opuscula Entomologica, supplementum, v.19, p.1-227, 1961. 
LANGE, R.B. Ensaio da zoogeografia dos Scarabaeidae do Paraná com algumas notas eto-ecológicas. Arquivos do Museo Paranaense, v.6, p.305-315, 1947.

LEE, J.M.; PENG, Y.S. Influence of manure availability and nesting density on the progeny size of Onthophagus gazella. Environmental Entomology, v.11, n.1, p.38-41, 1982.

LINK, D. Abundância relativa e fenologia de alguns Scarabaeoidea fototáticos, na zona de campos de santa Maria, RS. (Coleoptera). Curitiba, 1976. 79p. Tese (Doutorado) - Universidade Federal do Paraná.

LOBO, J.M.; MARTIN-PIERA, F.; VEIGA, C.M. Las trampas pitfall con cebo, sus possibilidades en el estudio de las comunidades coprófagas de Scarabaeoidea (Col.). I. Características determinantes de su capacidad de captura. Revue D'ecologie et de Biologie du Sol, v.25, n.1, p. 77-19 1988.

LOPES, P.P.; LOUZADA, J.N.C.; MELLO, F.Z.V. de; ARAÚJO, V.F.; SENA, M.P. Efeito da complexidade de vegetação na estrutura de comunidades de Scarabaeidae em quatro ambientes no campus da UEFS. In: CONGRESSO DE ECOLOGIA DO BRASIL, 3. Brasília, 1996. Resumos. Brasilia: 1996. p.153.

LOUZADA, J.N.C.; VAZ DE MELLO, F.Z.; LOPES, E.S. Estrutura da comunidade de Scarabeidae (Coleoptera, Scarabaeioidea) de uma cordilheira no pantanal Sul-Mato-Grossense. In: CONGRESSO DE ECOLOGIA DO BRASIL, 3. Brasília, 1996. Resumos. Brasilia: 1996. p.178. 
LOUZADA, J.N.C. Efeito da estrutura taxonômica regional sobre a estrutura de guildas local em comunidades de Scarabaeidae detritívoros (Insecta, Coleoptera). In: CONGRESSO DE ECOLOGIA DO BRASIL, 3. Brasilia, 1996. Resumos. Brasília: 1996. p.146.

LUEDERWALDT, H. As espécies brasileiras do gênero Pinotus (Coleoptera - Lamellicornidae - Coprini), com algumas considerações também sobre outras espécies. Revista do Museu Paulista, v.16, p.603-779, 1929.

LUEDERWALDT, H. O gênero Ontherus (Coleop.) (Lamellic-Coprid.Pinot.) com uma chave, para determinação dos pinotides americanos. Revista do Museu Paulista, v.17, p.363-422, 1931.

LUMARET, J.P.; KIRK, A. Ecology of dung beetles in the french mediterraneam region (Coleoptera: Scarabaeidae). Acta Zoologica Mexicana, n.24, p.1-55, 1987.

MACLINTOCK, J.; DEPNER, K.R. A review of the life-history and habits of the horn fly, Siphona irritans (L.) (Diptera: Muscidae). The Canadian Entomologist, v.86, p.20-33, 1954.

MATTHIESSEN, J.N.; PALMER, M.J. Prediction of temperatures in cattle dung for estimating development times of coprophilous organisms. Bulletin of Entomological Research, v.78, n.2, p.235-249, 1988.

MELVIN, R.; BECK, D.E. Lenght of the developmental Stages of the Horn-fly Haematobia irritans (Linne), at constant temperature. Journal of Economic Entomology, v.24, p.330-331, 1931 . 
MERRITT, R.W.; ANDERSON, J.R. The effects of different pasture and rangeland ecosystems on the dynamics of insects in cattle droppings. Hilgardia, v.45, n.2, p.31-71, 1977.

MOHR, C.O. Cattle droppings as ecological units. Ecological Monographs, v.13, n.3, p.275-298, 1943.

MOON, R.D. Simulating developmental time of preadult face flies (Diptera: Muscidae) from air temperature records. Environmental Entomology, v.12, n.3, p.433-438, 1983.

MOON, R.D.; LOOMIS, E.C.; ANDERSON, J.R. Influence of two species of dunt beetles on larvae of face fly. Environmental Entomology, v.9, n.5, p.607-612, 1980 .

MWANGAIA, F.S.; GALLOWAY, T.D. Susceptibility of horn flies, Haematobia irritans (L.) (Diptera: Muscidae), to pyrethroids in Manitoba. The Canadian Entomologist, v.125, n.1, p.47-53, 1993.

MYRCHA, A.; ANDRZEJEWSKA, L. Bioenergetics of the developmental period of the coprophagous beetles of Panamanian pastures. Ekologia Polska, v.31, n.2, p.219-244, 1984.

OLIVEIRA, G.P.; RODRIGUES, S.R.; GROMICK, M.B. Espécies de besouros fimícolas ocorrentes em áreas de pastagens em São Carlos, SP. In: CONGRESSO BRASILEIRO DE MEDICINA VETERINÁRIA, 24. Goiânia, 1996. Anais. Goiânia, 1996. p.153-154.

PAULIAN, R. Contribution a l'étude des canthonides américains [Coleopt. Lamellic.]. Annales de la Sociéte Entomologique de France, v.108, p.1-40, 1939. 
PECK, S.B.; FORSYTH, A. Composition, structure, and competitive behaviour in a guild of Ecuatorian rain forest dung beetles (Coleoptera; Scarabaeidae). Canadian Journal of zoology, v.60, n.7, p.1624-1634, 1982 .

PESSOA, S.B. Contribuição para o conhecimento das espécies brasilerias do gênero phanaeus (Col. Scarabaeidae). Annaes da Faculdade de Medicina da Universidade de São Paulo, v.10, n.3, p.279-314, 1934 .

PESSOA, S.B. Notas sobre o gênero Taurocopris, com a descripção de uma espécie nova (Col. Scarabaeidae). Annaes da Faculdade de Medicina de são Paulo, v.11, n.1, p.33-35, 1935.

RIDSDILL-SMITH, T.J. Selecting new kinds of dung beetles for better bush fly control. Journal of Agriculture of Western Australia, v.25, n.3, p.108-110, 1984.

RIDSDILL-SMITH, T.J. The effect of seasonal changes in cattle dung on egg production by two species of dung beetles (Coleoptera: Scarabaeidae) in south-western Australia. Bulletin of Entomological Research, v.76, n.1, p.63-68, 1986.

RIDSDILL-SMITH, T.J. Survival and reproduction of Musca vetustissima Walker (Diptera: Muscidae) and a scarabaeine dung beetle in dung of cattle treated with avermectin b1. Journal of the Australian Entomological society, v.27, n.3, p.175-178, 1988 .

RIDSDILL-SMITH, T.J.; HAYLES, L. Mortality of eggs and larvae of the bush fly, Musca vetustissima walker (Diptera: Muscidae), caused by scarabaeine dung beetles (Coleoptera: Scarabaeidae) in favourable cattle dung. Bulletin of Entomological Research, v.77, n.4, p.731-736, 1987. 
RIDSDILL-SMITH, T.J.; HAYLES, L. Stages of bush fly, Musca vetustissima (Diptera: Muscidae), killed by scarabaeine dung beetles (Coleoptera: Scarabaeidae) in unfavourable cattle dung. Bulletin of Entomological Research, v.80, n. 4, p. 473-478, 1990.

RIDSDILL-SMITH, T.J.; MATTHIESSEN, J.N. Controlling cattle dung and the bush fly. Journal of Agriculture of Western Australia, v.22, n.2, p.76-77, 1981.

RIDSDILL-SMITH, T.J.; MATTHIESSEN, J.N. Field assessments of the impact of night-flyung dung beetles (Coleoptera: Scarabaeidae) on the bush fly, Musca vetustissima walker (Diptera: Muscidae), in south-western Australia. Bulletin 6 Entomological Research, v.74, N.2, p.191-195, 1984.

RINALDI, I.M.P.; FORTI, L.C.; YASSU, W.K. Biologia de Canthon virens (Coleoptera, Scarabaeidae) predador de rainhas de (Hymenoptera, Formicidae) em condições de campo. In:CONGRESSO BRASILEIRO DE ENTOMOLOGIA, 14. Piracicaba, 1993. Resumos. Piracicaba: SEB, 1993. p.51.

RODRIGUES, L.R.A. Aspectos comportamentais dos besouros coprófagos em pastagens. In: ENCONTRO PAULISTA DE ETOLOGIA, 3. Ribeirão Preto, 1985. Anais. Ribeirão Preto: AZESP, 1985. p.95-103.

RODRIGUES, L.R.A. Os besouros coprófagos em pastagens. In: SIMPÓSIO SOBRE ECOSSISTEMAS DE PASTAGENS, Jaboticabal, 1989, Anais. Jaboticabal : FUNEP, 1989. p.97-133. 
RODRIGUES, S.R.; FLECHTMANN, Comparação da fauna de besouros coprófagos em área de mata ciliar, de transição e de pastagem em Selviria/MS. Resultados preliminares. In: CONGRESSO BRASILEIRO DE ENTOMOLOGIA, 14. Piracicaba, 1993. Resumos. Piracicaba: 1993. p.134.

RODRIGUES, S.R.; FLECHTMANN, C.A.H. Besouros coprófagos (Coleoptara, Scarabaeidae) em pastagem em Irati/PR. In: CONGRESSO DE ENTOMOLOGIA, 15. Caxambu, 1995. Resumos. Caxambu: 1995b. p.581.

RODRIGUES, S.R.; FLECHTMANN， C.A.H. Levantamento de besouros coprófagos (Coleoptera, Scarabaeidae) em Pereira Barreto/SP. In: CONGRESSO DE ENTOMOLOGIA, 15. Caxambu, 1995. Resumos. Caxambu: 1995a. p.580.

RODRIGUES, S.R.; MARCHINI, L.R. Besouros coprófagos (Coleoptera; Scarabaeidae) coletados em Piracicaba/SP. In: SIMPÓSIO DE CONTROLE BIOLÓGICO, 5. Fóz do Iguaçu, 1996. Anais. Fóz do Iguaçu: 1996, p.420.

RODRIGUES, L.R.A.; MARTINELLI, N.M.; REIS, R.A.; GARIB, M.B. Ocorrência de besouros coprófagos atraídos por excrementos de bovinos, equinos e ovinos. In: REUNIÃO DA SOCIEDADE BRASILEIRA DE ZOOTECNIA, 27. Campinas, 1990. Anais. Campinas: 1990. p.313.

SAUERESSIG, T.M. "Mosca-dos-chifres", Haematobia irritans: diagnóstico e controle. LOCAL: CPAC - EMBRAPA, 1992. 12p. (EMBRAPA-CPAC, Documentos, 43). 
SCOTT, F.B.; GRISI, L. Eficácia comparativa dos piretróides Alfametrina pour-on e da flumetrina pour-on no controle da mosca do chifre, Haematobia irritans em bovinos. In: SEMINÁRIO DO COLÉGIO BRASILEIRO DE PARASITOLOGIA VETERINÁRIA; SIMPÓSIO SOBRE A MOSCA-DOS-CHIFRES, São Paulo, 1991. Resumos. São Paulo: 1991. v.1, n.0, p.2-49.

SILVEIRA NETO, S.; NAKANO, O.; BARBIN, D.; NOVA, N.A.V. Manual de ecologia dos insetos. São Paulo: Ceres, 1976. 419p.

SOUTHWOOD, T.R.E. Ecological methods. 3.ed. London, Chapman a Hall, 1971, 391p.

STUMPF, I.V.K. Estudo da fauna de escarabeídeos em Mandirituba, Paraná, Brasil. Acta Biológica Paranaense, v.15, n.1/4, p.123-153, 1986.

STUMPE, I.V.K.; LUZ, E.; TONIN, V.R. Biologia de Ateuchus apicatus Harold, 1867. Acta Biológica Paranaense, v.15, n.1/4, p.63-85, 1986a.

STUMPF, I.V.K.; LUZ, E.; TONIN, V.R. Biologia de Ateuchus mutilatus Harold, 1867. Acta Biológica Paranaense, v.15, n.1/4, p.155-177, 1986b.

VALÉRIO, J.R. Haematobia irritans I.: um novo problema para a bovinocultura no Brasil. Campo-Grande: EMBRAPA-CNPGC, 1985. 4p. (EMBRAPA-CNPGC. Campo Grande, 25).

VALÉRIO, J.R.; GUIMARÃES, J.H. Sobre a ocorrência de uma nova praga, Haematobia irritans (L.) (Diptera, Muscidae), no Brasil. Revista Brasileira de Zoologia, v.1, n.4, p.417$418,1983$. 
WATERHOUSE, D.F. The biological control of dung. Scientific American, v.230, n.4, p.100-109, 1974.

WILCKEN, C.F. Estrutura da comunidade de lepidópteros, coletados com armadilhas luminosas, que ocorrem em florestas de Eucalyptus grandis Hill Ex Maiden. Piracicaba, 1991, 148p. Dissertação (Mestrado) - Escola Superior de Agricultura "Luiz de Queiroz", Universidade de São Paulo.

WILLIANS, R.E. Controle químico: prejuízos econômicos e estratégias de controle. In: SIMPÓSIO INTERNACIONAL SOBRE A MOSCA-DOS-CHIFRES Haematobia irritans, 1. São Paulo, 1991. Anais. São Paulo: 1991, p.29-30. 
APÊNDICE 
Apêndice 1. Limites para caracterização das espécies coletadas com armadilhas "pitfall", em área de pastagem.

\section{Índices}

faunísticos

Frequências

Frequencias

Abundancia

Abundância

Abundancia

Constância
Classificação

Pastagem

Muito Frequente (MF) $>1,67$

Frequente (F)

$<1,67>0,11$

Pouco Frequente (PF)

$<0,11$

Super abundante (SA)

$>5,65$

Abundante (A)

$<5,65>4,85$

Comum (C)

$<4,85>0,35$

Dispersa

(D)

Rara (R)

$<0,35>-0,44$

$<-0,44$

Constante (W)

$>12,10$

Acessória (Y)

Acidental (Z)
$<12,10>0,48$

$<0,48$ 
Apêndice 2. Limites para caracterização das espécies coletadas com armadilhas "pitfall", em área de Eucalyptus sp. com subbosque.

Índices

faunisticos

Erequências

Abundância

Constância
Classificação

Eucalyptus sp.
Muito Frequente (MF) $>5,44$

Erequente (F)

$<5,44>0,48$

Pouco Frequente (PF)

$<0,48$

Super abundante (SA)

Abundante (A)

$>6,85$

Comum (C)

Dispersa (D)

Rara (R)

$<6,85>5,99$

$<5,99>0,51$

$<0,51>-0,35$

$<-0,35$

$>6,57$

$<2,41$
Constante (W)

Acessória (Y)

Acidental (Z)
$<6,57>2,41$

Y) $\quad<6,57>2,41$

